\title{
Animal penning and open area activity at Neolithic Çatalhöyük, Turkey
}

Article

Accepted Version

Creative Commons: Attribution-Noncommercial-No Derivative Works 4.0

Portillo, M., Garcia-Suarez, A., Klimowicz, A., Barański, M. Z. and Matthews, W. (2019) Animal penning and open area activity at Neolithic Çatalhöyük, Turkey. Journal of Anthropological Archaeology, 56. 101106. ISSN 0278-4165 doi: https://doi.org/10.1016/j.jaa.2019.101106 Available at https://centaur.reading.ac.uk/87013/

It is advisable to refer to the publisher's version if you intend to cite from the work. See Guidance on citing.

To link to this article DOI: http://dx.doi.org/10.1016/j.jaa.2019.101106

Publisher: Elsevier

All outputs in CentAUR are protected by Intellectual Property Rights law, including copyright law. Copyright and IPR is retained by the creators or other copyright holders. Terms and conditions for use of this material are defined in the End User Agreement.

\section{www.reading.ac.uk/centaur}

\section{CentAUR}

Central Archive at the University of Reading 
Reading's research outputs online 


\title{
Animal penning and open area activity at Neolithic Çatalhöyük, Turkey
}

\author{
Marta Portillo ${ }^{\mathrm{a}, \mathrm{b}, \mathrm{c} *}$, Aroa García-Suárez ${ }^{\mathrm{c}, \mathrm{d}}$, Arkadiusz Klimowicz ${ }^{\mathrm{e}}$, Marek Z. Barański ${ }^{\mathrm{f}}$, \\ Wendy Matthews ${ }^{\mathrm{c}}$
}

a Department of Archaeology and Anthropology, Archaeology of Social Dynamics (2017SGR 995), Institució Milà i Fontanals, Spanish National Research Council (CSIC), Barcelona, Spain

${ }^{b}$ Department of Prehistory, Autonomous University of Barcelona, Bellaterra 08193, Spain

${ }^{c}$ Department of Archaeology, University of Reading, Whiteknights, Reading RG6 6AB, United Kingdom

${ }^{\mathrm{d}}$ Faculty of Oriental Studies, University of Oxford, Oxford OX1 2LE, United Kingdom

${ }^{\mathrm{e}}$ Faculty of Archaeology, Adam Mickiewicz University in Poznań, ul. Umultowska 89D 61-614 Poznań, Poland

${ }^{\mathrm{f}}$ Academy of Fine Arts in Gdańsk, Targ Węglowy 6, 80-836 Gdańsk, Poland

* Corresponding author. mportillo@imf.csic.es

\begin{abstract}
Over the last few decades a variety of geoarchaeological methods and ethnoarchaeological and experimental approaches have demonstrated the fundamental importance of animal dung deposits for reconstructing past human life-ways. Through simultaneous examination in micromorphological thin-section and integrated phytolith and faecal spherulite analyses, this study provides direct evidence for animal management and organisation of space at Neolithic Çatalhöyük by examining livestock penning deposits across the settlement. The identification of new extensive areas of penning distributed within the boundaries of the early occupation of the site suggests greater proximity to and management of herds immediately prior to a phase of settlement expansion, access to wider networks and resources, and increased exploitation of the wider landscape. Phytolith assemblages from in situ dung accumulations also provide new insights into foddering/grazing practices showing highly variable herbivorous regimes, including both dicotyledonous and grass-based
\end{abstract}


diets with an important proportion of grasses used as fodder and/or grazing during the early occupation of Çatalhöyük. This study provides direct evidence of the proximity of humans and herds, continuity and change in animal management strategies and farming practices, and concepts of space at the site.

\section{Highlights}

Animal dung is a valuable archaeological resource for reconstructing human activity.

An integrated geoarchaeological approach identifies new penning areas at Çatalhöyük.

Results suggest proximity to and management of herds preceding site expansion.

Foddering/grazing practices display highly variable regimes among herd animals.

Results show patterns of co-habitation of humans with animals, their food and dung.

\section{Keywords}

Neolithic, Çatalhöyük, early farming, micromorphology, phytoliths, faecal spherulites, livestock penning.

\section{Introduction}

Animal dung deposits are common in many archaeological contexts worldwide, especially since the domestication of herds. Substantial accumulations of dung as a result of animal corralling or livestock penning occur both off-site and within built environments, including in open-air and naturally sheltered sites such as caves and rockshelters, and in a wide variety of constructed enclosures (e.g. floored, walled, roofed, partially roofed or unroofed, etc.). Livestock dung is increasingly being regarded as a valuable archaeological resource as it contains critical information on the environment as well as on a range of ecological and socio-economic practices and cultural life-ways. Over the last decades, research concerning animal dung has highlighted its worldwide economic importance as a source of manure, fuel and tempering of construction materials, examining ways in which dung provides key information on the environment, plant and animal management, energy sources, socioeconomic relations and cultural practices (for a review on archaeological dung see Shahack-Gross, 2011 and Spengler, 2018). Further, animal dung and penning deposits have the potential to provide insights into the earliest stages of animal corralling, 
management and domestication (Di Lernia, 2001; Stiner et al., 2014), as morphological changes in the skeleton may be delayed by up to 500-1,000 years (Zeder, 2005). However, this potential has not been fully realised in archaeological research and in syntheses on the emergence and spread of early farming systems more widely.

To date, geoarchaeological, ethnoarchaeological and experimental studies on livestock dung and penning have made significant contributions to the study of animal management and domestication, herding practices, site formation processes, use of space and urbanization (Shahack-Gross, 2011, 2017, and references therein). A number of studies conducted on modern stabling deposits have investigated herbivore dung from domestic animals at the onset of food-production in the Old World, primarily sheep and goats, cattle, and other animals such as pigs as well as commensals, using a range of analytical techniques in geoarchaeology, archaeobotany and biochemistry (e.g. Brochier et al., 1992; Canti, 1999; Shahack-Gross et al., 2003, 2004; Macphail et al., 2004; Milek, 2012; Portillo et al., 2012, 2014; Elliott et al., 2015; Prost et al., 2017; Égüez et al., 2018). Ethnoarchaeological and experimental approaches provide comparative datasets and models on the formation processes of dung deposits from animal diet through to defecation, deposition, degradation and preservation within gathering enclosures, including the ecological and anthropogenic factors influencing these. Although over the last three decades a variety of geoarchaeological and biomolecular methods have been used to identify animal penning both in caves and rockshelters (e.g. Brochier et al., 1992; Karkanas, 2006; Delhon et al., 2008; Angelucci et al., 2009; Cabanes et al., 2009; Polo-Díaz et al., 2016), as well as within built environments and open settlement areas (e.g. Matthews et al., 1996; Shahack-Gross and Finkelstein, 2008; Albert et al., 2008; Portillo et al., 2009; Prost et al., 2017; Dunseth and Shahack-Gross, 2018), dung deposits are still overlooked or missed in most archaeological research programs. This is partly due to the methodological challenges involved in identifying faecal components both in the field and in a range of routine sampling strategies, as they may be disaggregated or lost during screening and flotation and are often dissociated from their depositional context during post-excavation processing. This frequently results in the loss of crucial evidence on site formation processes, taphonomy, and contextual data that are fundamental for identifying traces of faecal matter and interpreting their wider significance. 


\subsection{Case study}

Çatalhöyük, in Central Anatolia, provides an ideal case study for exploring animal penning, management strategies and early husbandry, including the assessment of changes in these practices through time, as animal management, agricultural resilience, plant use and food production have been extensively investigated at the site (e.g. Martin and Russell, 2000; Fairbairn et al., 2002, 2005; Asouti, 2005, 2013, Rosen, 2005, Russell and Martin, 2005; Atalay and Hastorf, 2006; Pearson et al., 2007, 2015; Ryan, 2011; Henton et al., 2012; Bogaard et al., 2013, 2017; Charles et al., 2014; Filipović, 2014; González Carretero et al., 2017; Kabukcu, 2018).

The site is located to the east of the present course of the Çarşamba River, in the Çumra District on the Konya Plain. Present-day environmental conditions in Central Anatolia, with hot, dry summers and cold, wet winters, and considerable seasonal temperature oscillations of over $20^{\circ} \mathrm{C}$ between the warmest and coolest months, give rise to a dominant semi-arid steppe vegetation that has been long impacted by human settlement and agro-pastoral activity, particularly grazing, over the last decades (Frrıncioğlu et al., 2007; Ayala et al., 2017). The Konya Basin is a closed pluvial basin that has actively responded to changes in climate and precipitation. Previous palaeoenvironmental reconstructions situated Çatalhöyük within a palaeolandscape dominated by wet conditions (Roberts et al., 1996, 1999; Boyer et al. 2006). More recent high-resolution coring suggests that the landscape was highly variable in time and space, with increasingly dry conditions from the early Holocene onwards (Ayala et al., 2017).

Settlement at the site encompasses two mounds, the Neolithic East Mound, continuously occupied from 7100 to 5950 cal BC (Bayliss et al., 2015), and the Chalcolithic West Mound, with strong evidence of a significant overlap in the occupation of both mounds starting in the late seventh millennium BC (Orton et al., 2018). The site was discovered by J. Mellaart in the late 1950s and excavated by his team from 1961 to 1965 (Mellaart, 1967). Renewed excavations by the Çatalhöyük Research Project directed by I. Hodder have been carried out from 1993 until 2017. As a result of the last few decades of extensive research, Çatalhöyük is internationally recognised as a key site for understanding Early Holocene settlement and lifeways with a very detailed record of Neolithic houses comprising tightly packed mudbrick architecture and extensive wall paintings (Hodder, 2006, 2007, 2013). Important 
surveys and excavations in the vicinity of Çatalhöyük are placing this community and settlement within its wider chronological and geographical context, including the identification of indications of earlier caprine management at the nearby site of Boncuklu and Aşıklı Hüyük, in Cappadocia (Baird 2014; Stiner et al. 2014; Baird et al., 2018; García-Suárez et al., 2018; Abell et al. 2019).

The archaeobotanical record has highlighted the importance of early crops such as hulled wheats including einkorn (Triticum monococcum), emmer (T. dicoccum) and the 'new' type glume wheat defined by Jones et al. (2000), naked barley (Hordeum vulgare var. nudum) and bread wheat (T. aestivum) (González Carretero et al., 2017). Pulses such as pea (Pisum sativum), lentil (Lens culinaris) and bitter vetch (Vicia ervilia) have also been documented on site, and the collection of a range of wild resources is attested by the presence of nuts and fruits as staple foods (e.g. almonds, acorns, pistachio, hackberry and figs) (González Carretero et al., 2017). Fuel-wood exploitation strategies focused primarily on Ulmaceae with a later switch to deciduous Quercus, whereas in the mid- to late Neolithic levels Juniperus becomes the most commonly used fuel-wood, reflecting long-term ecological patterns during the site occupation (Asouti, 2005; Kabukcu, 2018). Faunal assemblages have revealed insights into caprine herding (Ovis, Capra), mainly of sheep, the adoption of cattle domestication in the later levels of occupation, indications of changes in herding practices, hunting, cooking and commensality, as well as the symbolic value of faunal elements. The latter consist primarily of cattle (Bos primigenius) and other wild animals in special deposits (e.g. deer, equids, boar) (Martin and Russell, 2000; Russell and Martin, 2005, 2012; Russell et al., 2005, 2009, 2013; Pearson, 2013; Pearson et al., 2007, 2015; Henton et al., 2012). The later Neolithic occupation (ca. 6500-6000 cal BC) spans the adoption of domesticated cattle (Bos taurus) and the use of secondary animal products such as milk (Russell et al., 2005; Evershed et al., 2008).

Significantly, dung remains are relatively common materials at Çatalhöyük, in particular across open areas and midden deposits, as demonstrated through charred archaeobotanical assemblages (Fairbairn et al. 2005), as well as micromorphological observations of their depositional contexts (e.g. Matthews, 2005; Shillito and Matthews, 2013). Faecal matter can be identified in thin-section or spot smear slides by microscopic examination of microfossil concentrations of calcitic dung spherulites that originate in the digestive system of a variety of animals, but particularly herbivores 
(Canti, 1999), as well as often by the presence of comminuted plant remains and a laminated microstructure if trampled (Shahack-Gross 2011). In addition, biomolecular evidence from sterols and bile acids analysed with Gas Chromatography Mass Spectroscopy (GC/MS) allows the discrimination between human and animal defecators (Matthews et al., 1996, 2014; Matthews, 2005; Bull et al., 2005; Shillito, 2011, 2017; Shillito et al., 2011; García-Suárez et al., 2018). This integrated approach has enabled the identification of both ruminant dung and omnivore coprolites at Çatalhöyük, some of which have been proven by GC/MS to be human (Shillito et al. 2011, 2013). Faecal remains at this site have also been found to relate to dung-burning activities, pointing to the use of animal dung as fuel (Matthews, 2005; Rosen, 2005; Fairbairn et al., 2005; Ryan, 2011; Shillito, 2011; Bogaard et al., 2013, 2014; García-Suárez et al., 2018).

Dung deposits have been identified in other Neolithic sites in the Konya Plain, including the early agricultural site of Boncuklu (8300-7800 cal BC) and the Late Neolithic occupation of the Pınarbaşı rockshelter (6500-6000 cal BC), using an integrated micromorphological and microfossil methodological approach that explored change in animal management strategies through time (García-Suárez et al., 2018). However, none of the reported contexts related to in situ penning deposits. For a review of dung evidence on herd management strategies and penning, foddering/grazing practices, seasonality, ecological diversity, and dung use for secondary purposes in the Neolithic Konya Plain, see Portillo et al. (accepted). Previous work at Aşıklı Hüyük, in Cappadocia, applying integrated zooarchaeological, micromorphological and phytolith analyses, revealed the occurrence of early caprine management by $8200 \mathrm{cal}$ BC in Central Anatolia (Stiner et al., 2014).

The early occupation of the East Mound is characterised by extensive midden deposits, a pattern that continued throughout the history of the settlement (Matthews et al., 1996; Matthews, 2005; Shillito, 2011, 2017; Shillito et al., 2008, 2011; Shillito and Matthews, 2013). In the South Area, early midden deposits up to 4 metres deep extend spatially across open areas over more than 40 lineal metres, displaying sequences of alternating massive and finely stratified layers formed by domestic residues, including ash layers from fuel materials and discarded food remains such as bone and shell fragments. Interestingly, compacted dung deposits from penning were identified both in the field and in micromorphological thin-sections. These consist of two successive animal enclosures in Sp. 199 and Sp. 198 comprising penning sequences formed by 
compacted dung deposits (Matthews et al., 1996; Matthews, 2005; Cessford, 2007). In addition to these sequences, new penning deposits of similar date were identified in 2017 in Sp. 620, South Area, and in Sp. 630 in the North Area (Fig. 1). Like the penning sequences previously studied in the 1990s in Sp. 199 and Sp. 198 in the South Area, this identification in the field was based on the observation of highly organic deposits, which displayed abundant phytolith inclusions visible as white micro-lenses, a compact microlaminated structure, and, importantly, organic staining, manifested in the bright orange colour of some of these microlaminations caused by oxidation processes related to the weathering of plant fibers (Matthews and Portillo, 2017; Brönnimann et al., 2017). These new sequences were sampled for integrated geoarchaeological and plant and faecal microfossil analyses (Taylor, 2017; Matthews and Portillo, 2017). They were interbedded with thin layers of trampled midden-like deposits and overlain a thicker sequence of midden deposits in Sp. 620 (Fig. 1).

The location and topography of Sp. 620 suggest that it is likely associated with the penning deposits detected during the excavation of Sp. 199, dating to $c a .7000 \mathrm{cal}$ BC (Fig. 4 in Bayliss et al., 2015), although a break in the stratigraphic sequence has prevented the identification of this association in the field (Taylor, 2017).The penning sequence identified in Sp. 630, in the North Area, pre-dates the construction of Building 132 (Klimowicz, 2017; Matthews and Portillo, 2017). Although detailed radiocarbon dates are not available for this space yet, preliminary results from the Bayesian radiocarbon project show that B.132 was inhabited between ca. 6700-6650 cal BC. Consequently, absolute chronology places Sp. 630 around 250 years later than Sp. 620 in the South Area (Bayliss, pers. comm.).

The current study therefore expands the micromorphological and biomicrofossil evidence for animal management strategies and livestock penning at Çatalhöyük through the analysis of in situ stratigraphic sequences from the South and North excavation areas of the Neolithic mound, where potential contexts displaying laminated animal dung were identified. This paper investigates three main issues: (1) the nature, composition, depositional pathways, and taphonomy of faecal deposits; (2) animal management strategies, livestock diet, husbandry practices, and ecological diversity; and (3) micro-traces of activities in open areas and middens such as traces of dung, waste disposal, and fuel burning, as well as site formation processes and concepts of space and living conditions, including implications for health within the built 
environment. These issues are explored through the simultaneous examination of dungdeposits and associated contexts in thin-section micromorphology and integrated phytolith and dung spherulite analyses. This study focuses, in particular, on the early occupation and animal pens that preceded the expansion of the site and allowed a greater access to wider networks and resources and an increased exploitation of the wider landscape (Pearson et al., 2007, 2015; Pearson, 2013; Russell et al., 2013; Spencer Larsen et al., 2013; Matthews, 2018; Middleton, 2018).

\section{Materials and methods}

Penning deposits constitute ideal contexts for the study of animal management strategies and farming practices, as well as for the implications of these for the use space and built environment at the site. Microscopic examination of hypothesized dung remains from finely stratified deposits in resin-impregnated micromorphological thin section enables the identification of the formation processes and contextual associations of individual component and micro-strata at high-resolution. It is possible to distinguish between faeces from different faunal groups in thin section, notably between omnivore and large or small ruminants (Courty et al., 1991; Shahack-Gross, 2011). This differentiation can be made on the basis of: the size and shape of pellets where preserved; the groundmass, microstructure and related distribution, and the type and comminution of embedded components such as plant remains and bone fragments.

However, post-depositional taphonomic processes such as firing, compaction and weathering, can make identification more difficult (Brönnimann et al., 2017). Fresh dung materials tend to become compressed and trampled by animals within enclosures, resulting in a laminar microstructure displaying elongated plant tissues oriented subparallel to the occupation surface in cases when animals were fed on grasses, showing a microlaminated bedding (Macphail et al., 2004; Shahack-Gross, 2017, and references therein).

In this case-study, three samples were collected for thin section micromorphology by cutting blocks from stratigraphic sections in two open spaces: two samples from Sp. 620 in the South Area and one from Sp. 630 in the North Area (Matthews and Portillo, 2017) (Fig. 1). Details of sample provenance and contextual field descriptions are given in Tables 1 and 2. For further excavation records see Klimowicz (2017) and Taylor (2017). In addition to micromorphological samples, a total number of 56 spot sediment 
samples from the same contexts were selected for phytolith and dung spherulite analyses. These correspond to 18 spot samples examined in the field laboratory (nonchemically extracted, coded as sne), 19 extracted spot samples (s), and 19 extracted subsamples from the three micromorphological blocks prior to thin section manufacture (ss) (Table 3 and in Supplementary Material Tables S1 and S2). Block sub-sample examination enables a direct comparison between detailed quantitative microfossil data and thin section micromorphological observations. This integrated methodology allows investigation of the nature of plant and faecal micro-remains and dung composition, taphonomy and depositional pathways as direct evidence of animal management and farming practices, including grazing and foddering of herds. Many of the samples relate to compacted or trampled dung penning deposits observed during excavations in Sp. 620 , that were firstly examined in the field laboratory through pilot microfossil analyses (Matthews and Portillo, 2017). In each study area, sediment samples were also collected either above or below the sediments associated with these dung deposits, including mudbricks, and these served for comparison as reference or controls.

\subsection{Micromorphology}

Sediment blocks were oven dried at $40^{\circ} \mathrm{C}$ and impregnated under vacuum with epoxy resin to be subsequently hardened at $70^{\circ} \mathrm{C}$ for 18 hours. After cooling, a slice of approximately $1 \mathrm{~cm}$ thickness was cut from the face of interest of the block using a diamond saw, and later trimmed. Each cut slice was then impregnated on a hot plate at $40^{\circ} \mathrm{C}$ with a mixture of Araldite epoxy resin, temporarily mounted on glass media, and placed in a Brot grinder-polisher before permanent mounting to a glass slide. Samples were then grinded to a standard thickness of $30 \mu \mathrm{m}$ and coverslipped. Slides were examined using a Leica DMLP microscope at magnifications from $\times 25$ to $\times 400$ under plane, cross-polarised, and fluorescent light. Digital images were obtained using a DFC420 camera and LeicaV2.3 image analysis software. Samples were described following standardised micromorphology guidelines (Stoops, 2003). The deposits analysed have been classified according to diagnostic microscopic attributes, including microstructure, coarse-fine fraction, orientation, sorting, and nature and frequency of mineral and organic components. Inclusions were identified through comparison with published materials and the extensive reference collection of archaeological, 
ethnographic and experimental thin-section slides available at the University of Reading.

\subsection{Phytolith analysis}

Phytolith analyses followed the methods of Katz et al. (2010). A weighed aliquot of 40 mg of dried sediment was treated with $50 \mu \mathrm{l}$ of a volume solution of $6 \mathrm{~N} \mathrm{HCl}$. Phytoliths were then concentrated with $450 \mu \mathrm{l} 2.4 \mathrm{~g} / \mathrm{ml}$ of sodium polytungstate solution $\left[\mathrm{Na}_{6}\left(\mathrm{H}_{2} \mathrm{~W}_{12} \mathrm{O}_{40}\right)\right]$. Aliquots of $50 \mu \mathrm{l}$ of sample were mounted on microscope slides. Phytoliths were examined in random fields at $200 \times$ and $400 \times$ magnification using a Leica DMEP optical microscope. A minimum of 200 phytoliths with diagnostic morphologies were counted following Katz et al. (2010) standards. Photomicrographs were captured with a Leica DFC420 camera. Morphological identification was based on modern plant reference collections and standard literature (Twiss et al., 1969; Brown, 1984; Piperno,1988, 2006; Rosen, 1992; Twiss, 1992; Mulholland and Rapp, 1992; Albert and Weiner, 2001; Tsartsidou et al., 2007; Albert et al., 2008, 2016; Portillo et al., 2014). Where appropriate, the terms used to describe phytolith morphologies follow the standards of the new International Code for Phytolith Nomenclature- ICPN 2.0 (Neumann et al., 2019).

\subsection{Dung spherulite analysis}

The methods used are similar to those developed by Canti (1999). Microscope slides were mounted with about $1 \mathrm{mg}$ of dried sample using Entellan New (Merck). Spherulites were counted at $400 \times$ magnification under the optical microscope with cross-polarized light. Spherulite numbers found in randomly chosen fields were recorded and related to the initial sample weight. The initial weight in rich-dung samples was of around $0.5 \mathrm{mg}$ in order to avoid microfossil overloading (Portillo et al., 2017).

During excavation, the presence of both dung spherulite and phytoliths was assessed in the field laboratory by examination of spot-smear slides made by mounting $\sim 1 \mathrm{mg}$ of air-dried non-extracted sediments on glass-slides with 3-4 drops of clove oil for testing the potential of the selected contexts (Matthews and Portillo, 2017). These non-permanent slides were examined using a Nikon SMZ645 polarizing microscope. The results were later re-evaluated after chemically extracted analyses through 
comparisons with modern reference materials from the Konya plain (Portillo and Matthews, accepted). Samples were also compared to phytolith and spherulite ethnoarchaeological datasets of modern livestock dung remains and soils from enclosures from Mediterranean regions that have followed a similar quantitative approach (Tsartsidou et al., 2008; Portillo et al., 2012, 2014, 2017).

\section{Results}

\subsection{Micromorphological observations}

\subsubsection{Space 620, South Area}

Micromorphological blocks 23214.s10 and 23214.s11 comprise midden and penning sequences in Sp. 620, South Area (Matthews and Portillo, 2017) (Fig. 1). This space is situated next to Building 162, which is most likely contemporary with Sp.620 and constitutes the earliest structure within a column of buildings in this area of the mound. The location and topography of the dung layers identified under the microscope suggest that these are likely contemporary with penning deposits detected in Sp. 199 during the 1999 excavation of the deep sounding and described by Matthews (2005). Figure 2 shows a synthetic diagram of the microstratigraphy in sample 23214.10 as defined with micromorphology, representative of the depositional sequence in this space, which comprises a series of trampled dung deposits interbedded with microunits of middenlike deposits that also contain trampled dung aggregates, and overlain by mixed midden deposits rich in charred plan materials. The analysis of these samples resulted in the identification of six microfacies (Table 4). These have been defined according to diagnostic microscopic attributes and inclusions, including microstructure, groundmass, sorting, and nature and frequency of components.

The midden-like deposits classified as microfacies 1a consist of a vughy matrix formed primarily by minerogenic materials with no traces of animal dung, and a small proportion ( $\mathrm{ca} .10 \%$ ) of charred plant fragments and phytoliths (Fig. 3a). The homogeneity of these units, in addition to the random orientation and distribution of its components, point to slow accumulation through dumping, and the action of reworking processes. These deposits, occurring between dung microlayers, appear to represent a hiatus in the use of Sp. 620 as a penning location. The layers identified as microfacies $1 \mathrm{~b}$ show a heterogeneous fabric of unsorted mixed inorganic and organic components, the latter including subangular bone and shell fragments, phytoliths, Chenopod 
endocarps, and charred plants ranging in size between $50 \mu \mathrm{m}$ and $1.8 \mathrm{~mm}$. These highly minerogenic contexts are similar to microfacies 1a, displaying abundant rounded inclusions of unburnt and partly charred calcareous, silty clay, and clay loam sediment aggregates likely to derive from discarded mixed hearth and floor sweepings from food preparation areas within buildings. Discrete dung lenses are present in variable proportions in these units, ranging between $10-25 \%$. These aggregates, measuring 1.5-3 $\mathrm{mm}$ in length and $0.5-1 \mathrm{~mm}$ in thickness, show a strong parallel orientation and distribution with respect to the unit boundaries. Frequent components of midden deposits at this site, such as minerogenic aggregates, sands and charred plant flecks are found embedded in these faecal lenses, probably an effect of trampling resulting in mixing and compaction (Fig. 3b). These spherulite-rich dung lenses become more abundant towards the upper and lower boundaries of the midden layers, which occur between penning deposits. This pattern appears to suggest a gradual increase in the frequency of use of this midden space as a pen during specific intervals, possibly related to seasonal cycles.

Microfacies 2, identified in sample 23214.s11, corresponds to a thin (3-4 mm) layer of loose dung- and grass-derived calcitic ash microaggregates containing few embedded charred monocotyledonous fragments and herbaceous siliceous remains. Amorphous aggregates of burnt dung with degraded spherulites have been observed to occur randomly and in moderate proportions (Fig. 3c). This microstratigraphic unit, situated immediately on top of the latest penning deposit in Sp. 620, appears to represent a single episode of fuel refuse formed predominantly by calcitic plant and dung ashes, possibly deposited with the goal of sanitising this area of faecal accumulations to reduce odours and insect breeding (Pawłowska, 2014).

Penning deposits described as microfacies 3 a comprise compacted parallel microlayers of herbivore dung displaying excellent phytolith and spherulite preservation (Fig. 3d and 4). Calcium oxalate druses, derived from dicotyledoneous plants, have also been documented in these deposits (Fig. 4a). The frequent occurrence of humification and oxidation processes caused by the decay of organic matter resulted in the bright orange-brown colouration of these units, which made them clearly distinguishable in the field (Fig. 5d). A few interbedded lenses of midden-like materials containing charred plant flecks have been detected in these units, possibly redeposited from other areas and incorporated into these dung deposits through trampling. 
Units classified as microfacies $3 \mathrm{~b}$ are formed by several superimposed, undulating herbivore dung microlayers displaying a strong parallel and sub-parallel orientation. These deposits are constituted by approximately 50\% herbaceous phytolith strands showing the microlaminated structure that characterises penning deposits, with plant fibres reoriented perpendicular to the force of trampling as a result of compaction due to the weight load of animals (Fig. 3e). The number of calcitic spherulites observed in thin-section is considerably lower than in microfacies 3a, likely due to post-depositional dissolution in a more acidic environment. Calcareous dung spherulites are known to dissolve in acidic conditions with a $\mathrm{pH} \leq 7$ (Canti, 1999), and in these units their absence is probably related to a post-depositional uric-saturated environment, an effect of sustained penning practices in this area (Shahack-Gross et al., 2003; Shahack-Gross, 2017). Greyish dung layers, such as these identified in the lower levels of the two sequences from Sp. 620 analysed in this study, were also documented by Matthews (2005) in Sp. 199 and Sp.198, South Area, and were reported in discussion with the local foreman at the time of excavation in 1999 as the result of over-saturation of pen deposits with urine.

Microfacies $3 \mathrm{c}$ is constituted by thin ( $c a .2-5 \mathrm{~mm}$ ) mixed deposits of trampled, substantially degraded herbivore dung and midden materials characterised by a low phytolith content and an absence of calcareous spherulites (Fig. 3f). This is probably again due to spherulite dissolution caused by uric acid saturation, lack of aeration, and possibly long-term exposure of these layers. Randomly oriented and distributed sandsized fragments of charred monocotyledons are ubiquitous throughout these units. Accumulation through multiple depositional events is evident in the variability shown by the abundant discrete dung lenses identified in these layers, which display varying degrees of organic staining and phytolith content. The high proportion of minerogenic and midden-like materials in these units, which include calcareous aggregates likely derived from architectural materials (Matthews, 2005), suggests cyclicity of activities involving animal penning and refuse discard, resulting in the post-depositional mixing of dung and midden remains through trampling.

\subsubsection{Space 630, North Area}

In thin section, this sequence comprises heterogeneous midden deposits overlain by $>2 \mathrm{~cm}$ of in situ compacted micro-laminations of trampled herbivore dung with faecal 
spherulites and phytoliths from a period of animal penning (sample 23616.s1, Fig. 1). The parallel oriented linear lenses of dung (Fig. 4b-c) resemble those from ethnographic samples of animal pens in the region (Anderson and Ertug-Yaras, 1998; Portillo and Matthews, accepted) and microfacies $3 \mathrm{~b}$ in $\mathrm{Sp}$. 620. Their greyish brown colour and absence of calcitic spherulites point to the prevalence of acidic post-depositional conditions in this space. Where spherulites are preserved they are often in oxidized reddish-brown dung deposits in this thin-section and those from other penning areas at the site such as Sp. 198 and Sp. 199 (Matthews et al., 1996; Matthews, 2005). On top of these penning deposits lies a unit of heterogenous midden materials that contains few lenses of animal dung displaying strongly parallel referred orientations. The overlying in situ burnt surface includes traces of dung mixed with diverse occupation residues including burnt bone and charred plant remains. Several fire spots were described in this space during excavation (Klimowicz, 2017). The charred plant inclusions and dung aggregates observed in this combustion feature suggest the use of mixed fuel sources, a frequent firing strategy at Çatalhöyük (e.g. Matthews, 2005, Shillito and Matthews, 2013). The uppermost deposits sampled consist of mixed layers of dung and minerogenic deposits and traces of a later episode of in situ burning, including of dung, which had similarly blackened and rubified underlying layers (Matthews and Portillo, 2017; García-Suárez et al., forthcoming).

These observations indicate that this area, like Sp. 620 in the South Area, was used as a pen for herbivores, at least periodically for sustained periods, as suggested by the sequence of banded compacted dung microlayers. Contrary to Sp. 620, these deposits were not recognised in the field as pen deposits partly because the layer of in situ-banded penning deposits had not yet been excavated and both this and the upper layer with more trampled dung were pal brown in colour, rather than the characteristic 'orange' brown of the other three penning areas identified by microstratigraphic analyses in the field.

\subsection{Phytolith assemblages}

Phytolith concentrations in most of the samples range between 0.5 and 9.3 million per 1 g of sediment (Table 3). The only exceptions are mudbrick control samples with around 0.3-1.4 million phytoliths/g sediment. The morphological results show that monocotyledonous phytoliths dominated in most of the assemblages, with around $70 \%$ 
or more of all the counted morphotypes (Tables S1 and S2). Interestingly, phytoliths from dicotyledonous leaves were noted in high proportions in dung-rich samples from microfacies 3a in Sp. 620 in the South Area (unit 23214, up to 40\%, Figs. 6a-b). This is especially noteworthy given that dicotyledonous plants are minor phytolith producers. In addition, diagnostic morphotypes from the Cyperaceae family (sedges) and reeds (Arundinoideae subfamily), which are commonly found in wetlands, were noted in most of the samples, although to a lesser extent. Grass phytoliths mostly belonged to the Pooideae subfamily, also common in well-watered environments. Epidermal appendage morphotypes from grass leaves and stems, including blocky and flabellate bulliforms, stomata, and acute bulbosus (trichomes), were observed in all the samples in different amounts (Fig. 6c). Additionally, grass phytoliths derived from their floral parts were abundantly noted in certain samples belonging to ashy and organic mixed deposits ( $c a$. $30 \%$ or more of all grass morphotypes). Grass inflorescences were characterized mainly by elongate dendritic and dentate phytoliths in addition to epidermal cells such as papillate. The latter morphologies which are considered as delicate or fragile cells (Cabanes et al., 2011) in association with the relatively low index of weathered morphotypes (average around 6.5\%), suggest a general good state of preservation of the assemblages.

\subsection{Faecal spherulite assemblages}

Dung spherulite concentrations range between 0.1-76 million spherulites/g sediment, with the only exception of mudbrick control samples, where these calcitic microfossils were almost absent (Table 3). The richest sediments by far were samples from microfacies 3a in Sp. 620 in the South Area (unit 23214, more than 40 million spherulites/g sediment), which show also large abundances phytoliths, mainly produced by dicotyledonous leaves (between 2-4.5 million phytoliths/g of sediment). Microfossil associations and micromorphological observations indicate that these plant materials were deposited onsite as a component of dung sources, likely derived from ruminants, which are prolific producers of calcitic spherulites (Canti, 1999).

\subsection{Integrated microfossil results by deposits and contexts}

The following section examines the variations and associations of the microfossil assemblages described above considering the main depositional contexts as reported in 
the micromorphological results. We provide a general overview of microfossil composition and the broad variations among these main contexts: compacted dung layers, mixed deposits, and in situ burned deposits. We examine phytolith and dung spherulite assemblages from each of the selected contexts, as well as other biogenic microfossils such as diatoms and, to a lesser extent, sponge spicules present in the phytolith slides (Fig. 6e). Both diatoms and sponge spicules may potentially serve as indicators of well-watered environmental conditions (Wilding and Drees, 1971; Schwandes and Collins, 1994; Coil et al., 2003). Their co-association with phytoliths indicates a generally good state of preservation of the silica assemblages. Furthermore, in most of the samples diatom abundances overlap not only with large numbers of phytoliths, but also with dung spherulites. Diatom silica frustules are found in fresh or salt water and in conditions where moisture is present (e.g. soils, deposits, and building materials), but fresh water diatoms can also be found in dung resulting from ingested matter and drinking, as reported in many geo-ethnoarchaeological studies (Brochier et al., 1992; Portillo and Albert, 2011; Shahack-Gross, 2011; Portillo et al., 2012, 2014).

\subsubsection{Compacted dung-rich deposits}

Both phytoliths and dung spherulites were abundant in all compacted or trampled dung sediments defined as penning deposits by the micromorphological analyses (Table 3). The highest amounts of both microfossils were found in block sub-samples 23214.s10 and associated spot samples (microfacies 3a), whereas these appear to have abundances that are more variable in samples from block 23214.s11 from the same unit in Sp. 620, in the South Area. This is possibly related, in certain cases, to post-depositional processes resulting in mixing of faecal and midden components in specific layers and lower spherulite numbers, also possibly due to post-depositional dissolution in more acidic conditions related to urine accumulation, as observed through micromorphology (microfacies $3 \mathrm{~b}$ and 3c). Notably, the penning deposits in Sp. 620 are well preserved, displaying very few physical disturbances caused by soil microfaunal bioturbation. The dominant morphotypes in both assemblages are epidermal appendages or multi-celled phytoliths produced by the leaves of dicotyledonous plants including hairs and their epidermal bases, as well as tracheary and polyhedral multi-cells to a lesser extent (Figs. 6a-b).This vegetal microfossil content in association with large concentrations of dung spherulites, which were also noted in undisturbed deposits in thin section, are suggested 
to derive from ruminant faecal matter, showing a diet that is either based on or includes a leafy component (Rasmussen, 1989; 1993; Macphail et al., 1997; Karg, 1998; Halstead and Tierney, 1998; Delhon et al. 2008; Schepers and Van Haaster, 2015). According to modern reference livestock dung datasets from geo-ethnoarchaeological studies conducted in several Mediterranean areas (Tsartsidou et al., 2008; Portillo et al., 2012, 2014, 2017), as well as in Central Anatolia (Portillo and Matthews, accepted) ruminants are prolific producers of dung spherulites, although the variations in their formation and abundance in relation to ecological and seasonal variability in dietary practices or sex/age-based aspects are not yet fully understood.

In contrast, trampled dung deposits from Sp. 630, located in the North Area (sample 23616.s1) showed larger and more variable proportions of grass phytoliths in association with relatively lower concentrations of dung spherulites (Table 3, Figs. 7 and $8 \mathrm{a}-\mathrm{b}-\mathrm{c})$. This may relate to different animal defecators and, therefore, it could reflect diet input, although the occurrence of post-depositional taphonomic processes involving microfossil dissolution has been observed in thin section. Micromorphological analyses have also documented the presence of discontinuous dung lenses throughout the stratigraphic sequence, showing trampling and compaction indicators, akin to those detected in Sp. 620 (microfacies 1b). These deposits display a similar microfossil composition, also dominated by morphotypes from the leaves and stems of Pooideae grasses in addition to smaller proportions of reeds, but comparatively in higher anatomical connection, an aspect that could be related to the absence of mechanical degradation due to heavy trampling (multicellular phytoliths reaches $c a$. 29\%, Table 3, Fig. 8c). These depositional sequences also may represent herbivorous dung accumulations, as suggested by dung spherulite abundances. In general, and in contrast with the dicotyledonous-rich dung deposits from microfacies 3a in Sp. 620 reported above, phytolith results suggest that the leaves and culms of grasses may have been used as fodder and, therefore, also as bedding. Furthermore, the abundance of Pooideae grasses and reeds, in addition to the presence of diatoms and sponge spicules that are considered indicators of well-watered conditions, suggest the exploitation of local wetland environments.

\subsubsection{Mixed and in situ burned deposits}


Many of the midden layers observed in the depositional sequences from both spaces display a faecal component, indicated by the presence of dung aggregates and calcitic spherulites noted both in thin section and in associated sediment samples. These deposits show the most variable amounts of both phytoliths and dung spherulites, and many are associated with ashy materials and charred remains (Table 3). Some of these assemblages display relatively high concentrations of spherulites, suggesting the occurrence of substantial accumulations of herbivore faecal matter in these layers. The deposits classified as microfacies $1 \mathrm{~b}$, in particular, appear to have formed by the slowly accumulation of materials through the dumping and re-deposition of domestic residues in Sp. 620. The occurrence of compacted, undulating and continuous dung aggregates in these deposits indicate short-lived events involving the use of this space for in situ penning activity, the increasing frequency of which led to the formation of penning units (microfacies 3a, 3b and 3c), representing sustained stabling conditions (Fig. 2). Overall, these mixed assemblages show larger and more variable proportions of monocotyledonous phytoliths, including Pooideae grasses, reeds and sedges (Tables S1 and S2). Microfossil associations suggest that these plants might have had a significant role as fuel and/or fodder. Also remarkable is the presence of morphologies derived from the floral parts of these plants in certain layers. The richest concentrations were found in midden deposits from microfacies 1a in Sp. 620 in the South Area, and appear to derive from the husks of cereals such as wheat (between $30 \%$ and $56 \%$ of the grass morphotypes). Their presence could potentially constitute a seasonal marker (e.g. Delhon et al. 2019), although plant or faecal materials collected in any season of the year may have been stored for a later use (e.g. Anderson and Ertug-Yaras, 1998).

The occasional presence of phytoliths showing evidence for partial melting observed in deformations caused by high temperatures, is also significant in mixed midden deposits (Fig. 8e), in association with darkened spherulites which are commonly produced at temperatures between $600-700^{\circ} \mathrm{C}$ (Canti and Nicosia, 2018), thus providing some insights into firing activity. Darkened spherulites were also common in ashy deposits from an oven located in the same open space in the South Area (units 23212, 23215 and 23216, oven F8044, Table 3) which are included in this study for comparative purposes. The deposit sequences examined in thin-section also showed episodes of in situ burning, including of herbivorous dung, in addition to burnt bones, 
charred plant remains, and articulated or multi-celled grass phytoliths (samples 23616.s1.ss1 and ss4).

\section{Discussion}

\subsection{Variation of deposits in open areas and animal penning}

By integrating micromorphological and microfossil examinations, this study has contributed to the investigation of formation and post-depositional processes in the Neolithic mound, illustrating the variability of deposits and their microfossil composition, and the complexity of activities found in different areas of the early settlement. This integrated approach has resulted in the identification of substantial accumulations of faecal remains derived from herbivorous penning, re-deposited layers of mixed burnt and non-burnt remains in middens, and in situ combustion of plant and dung materials as mixed fuels, where microfossil dung evidence from spherulites is less abundant or even scarce. Their significance and implications for animal management strategies, foddering, early husbandry practices, and use of space at Çatalhöyük are discussed in detail below.

The earliest occupation of the South Area displays repeated midden sequences up to 4 meters deep, as previously observed in open areas located in the deep sounding (Cessford, 2007). Open spaces are ubiquitous throughout the lifetime of the site, demonstrating that midden deposits constitute an important part of the archaeological record at Çatalhöyük (Matthews et al., 1996; Matthews, 2005; Shillito, 2011, 2017; Shillito and Matthews, 2013; Shillito et al., 2008, 2011). Recent excavations in open spaces Sp. 628 and Sp. 620, reported here, have revealed extensive deposits particularly rich in discarded fuel, production debris and food waste, with inclusion of coprolites, charred dung aggregates, and herbivorous dung deposits (Matthews and Portillo, 2017; García-Suárez et al., forthcoming). Previous studies show that animal dung was also burnt as fuel in open areas at the site, possibly related to the performance of specific activities in these spaces, including in the manufacture of architectural materials (Matthews, 2005; García-Suárez et al., 2018). Therefore, the excellent preservation conditions of large fragments of charred wood, anatomically connected or articulated silica plant micro-remains, and non-abraded aggregates of unfired plaster fragments noted during excavation, particularly in Sp. 628, suggest that this sequence was not heavily trampled and may have generally been primarily used for waste disposal. 
Together with Sp. 181 in the deep sounding, this evidence indicates that significant sectors of the settlement were not used for housing throughout the history of the site, but rather for discard and disposal practices. Other activities such as livestock penning were conducted in spaces that had a history of use as middens, particularly in earlier levels in the South Area as illustrated in Sp. 620, as well as in Sp. 198 and Sp. 199. The penning spaces may have been roofed as attested by: the excellent preservation of micro-laminated dung and plant remains that resemble modern ethnographic examples of roofed pens (Anderson and Etug-Yaras, 1998; Portillo and Matthews, accepted); walls associated with Sp. 198 and Sp. 199 (Figs. 4.16-22 in Cessford, 2007), and postholes in Sp. 630 (Table 1).

The recently discovered in situ compacted dung deposits represent two out of only four known areas of substantial herbivore penning within the boundaries of the site as identified through thin section micromorphology, all of which correspond to the early occupation of the settlement (Mathews, 2005; Matthews and Portillo, 2017; GarcíaSuárez et al., forthcoming). Thin section observations indicate that $\mathrm{Sp}$. 620 was a penning space in a yet undefined area with a $c a .5 \mathrm{~cm}$ deep sequence of trampled herbivore dung deposit particularly rich in calcitic spherulites and articulated phytoliths displaying a rich dicotyledonous diet, sometime prior to the construction of Building 17. Naturally-deposited sediments such as water-laid lenses or crusts have not been detected in thin-section. The absence of these features, however, does not necessarily confirm the possibility that the space was completely or partially unroofed, as they are also surprisingly rare in midden deposits. Therefore, the presence of roofing remains a possibility based on the well-preserved microlaminations that are likely to have been much more reworked by trampling in wet conditions caused by rain and snowmelt in open conditions. Microfacies $1 \mathrm{~b}$ points to the dual nature of Sp. 620 and its use both as a discard location and an area of in situ activities such as animal penning. It is possible that the alternation between pen and mixed midden deposits observed in this sequence is related to seasonal and life cycles. In fact, since it has been hypothesized that pens could have provided shelter for animals during winter months, particularly to sick, pregnant and newly born animals (Matthews, 2005), there is a possibility that the interspersed trampled dung aggregates found in midden units represent discrete penning periods of particularly vulnerable animals. Further, the discontinuity of the dung lenses in the midden units might be indicative that only a specific area of Sp. 620 was used for 
penning during these episodic events. Micromorphological observations point to an increase in the frequency and duration of penning activities with depth in Sp. 620, culminating in the sustained penning represented by microfacies 3 . These findings illustrate that extensive areas devoted to penning activity were distributed within the boundaries of the earliest occupation of the South Area.

Of particular note is the identification of a penning sequence in Sp. 630 located in the North Area, described by the excavators as an 'open, unroofed and widely accessible space of a unique character' (Klimowicz, 2017). Little evidence was recorded in the field to indicate its purpose. Apart from possible post placements for a light roof or 'sort of temporary shelter or shade, rather than a permanent residential/domestic structure' within the area, there were also uncovered low and poorly constructed partitions in the south, along with randomly dispersed fire-spots. This space was sampled for integrated geoarcheological analyses to investigate whether this represented an open or roofed area and to study the formation processes and use-history of this space (Klimowicz, 2017; Matthews and Portillo, 2017). Micromorphological and microfossil associations revealed a depositional sequence with heterogeneous midden deposits overlain by $>2 \mathrm{~cm}$ of compacted in situ banded herbivore dung composed mainly by the leaves and stems of Pooideae grasses and spherulites related to a period of animal penning, followed by midden deposits overlain by traces of later episodes of in situ burning with blackened and rubefied underlying layers. The presence of wellpreserved, finely-banded dung deposits suggests that this area may have been at least temporarily roofed, while the randomly placed fire-spots noted across the area represent episodic use of fire perhaps for heating and/or cooking. Evidence of formallyconstructed fire features, such as rims or baked clay superstructures, has not been found, and this may represent an intentional decision of setting or keeping the fire open and unrestricted. The presence of this type of small fires within penning areas has been reported in the early occupation phases at Çatalhöyük, and this has been interpreted as related to a preceding burial (Cessford, 2007). However, as these fires directly precede the penning, they may also have been associated with warming and speculatively fumigating this space immediately prior to occupation by animals. In the case of Sp. 630 , the fire spot analysed in thin-section is stratigraphically separated from the penning deposits by $c a .1 .5 \mathrm{~cm}$ of midden accumulation. Significantly, this represents the only 
evidence for livestock penning within the North Area of the settlement to date, as identified through micromorphology.

Both dung sequences represent direct evidence for the penning of animals within the boundaries of Çatalhöyük during its early occupation $c a .7000$ and $6700 \mathrm{cal} \mathrm{BC}$, respectively. The previously known areas of animal penning identified in thin-section are located in the South Area of the Neolithic mound. One of these consists of successive penning deposits in Sp. 199 and Sp. 198 showing dung accumulations, each currently $c a .15 \mathrm{~cm}$ thick and arguably representing a single season use, less than seven meters to the west from those investigated in Sp. 620 (Matthews, 2005; Cessford, 2007). These consisted of strongly parallel fine layers of dung likely accumulated under roofed conditions, with occasional trampled aggregates of midden-like materials. This sequence suggests that penning activity occurred periodically, likely associated with seasonal animal life-ways such as birthing and farming cycles or socio-cultural activities (Matthews, 2005). The second known penning area also corresponds to deep, compacted animal dung deposits exposed also in the South Area through cleaning and sampling of sections from Mellaart's excavations in Court 25/15 (Matthews et al., 1996, 310-11, 322-4, Photographs 15.17-22). In addition, coprolite-rich deposits were reported in the fill of the main-room of Building 2, Sp. 117 in the South Area, occasionally described and depicted as representing an animal pen based on field observations (Regan, in Farid, 1997; Farid 2007). However, micromorphological studies identified these as omnivore faeces and unlikely to represent penning deposits due to the lack of sediment compaction and random distribution amongst aggregates of construction materials and calcitic silty clays (Matthews, 2005). Biomolecular analyses of samples from this context have identified these remains as human coprolites (Fig. 4a in Shillito et al., 2011). These results supported initial hypotheses based on micromorphological observations of Building 2, which interpreted these faecal accumulations as derived from probable latrine deposits mixed with large lime-rich aggregates at the end-life of this building to sanitize the area (Matthews, 2005, 379). The discrimination between animal and human faeces through biomolecular analyses is a key issue, as these materials are potential biomarkers for livestock and/or early settled human diet and health, with significant implications for understanding use of space within built environments. 


\subsection{Animal management, diet and early husbandry}

Although in situ penning areas are still rare at the site, and mostly documented in the South Area of the East Mound, these provide important sources of new data relevant to the reconstruction of early animal management, diet, husbandry, and ecology. Micromorphological observations, together with phytolith and dung spherulite associations, appear to indicate differences in animal diet composition. Specific phytolith morphotypes and other silica biomicrofossils could potentially be used as water availability indicators and possibly seasonal markers, thus providing insights into animal management and its implications for current debates on palaeoenvironment in addition to human activity and palaeoeconomy at Çatalhöyük East. Of particular note in this study is the diversity of livestock diet observed within penning deposits across different areas over time at the site. In the earliest occupation of the South Area the phytolith composition, in association with the overwhelmingly high concentrations of dung spherulites noted in $\mathrm{Sp} .620$, are suggested to derive from ruminant faecal matter showing a diet that is either based on or includes an important component of dicotyledonous leaves. This is especially noteworthy given that dicotyledonous plants are minor phytolith producers. In turn, dung spherulites are known to derive from a variety of animals although most abundantly in ruminants (Canti, 1999; Korstanje, 2005), but the mechanisms underpinning their formation remain poorly-defined, with soil $\mathrm{pH}$, seasonality, sex/age-based differences in dietary calcium intake requirements and feed $\mathrm{Ca}$ availability, and variable intestinal microflora have been suggested as possible variables (Brochier et al., 1992; Canti, 1999; Dalton and Ryan, 2018). A diet enriched in dicotyledonous leaves may suggest human manipulation of livestock and leaf-foddering strategies, or may also relate to possible selection by obligate browsers, such as caprines. Therefore, this pattern may reflect some degree of seasonality and relate to autumn/winter vegetation (Rasmussen, 1989, 1993; Macphail et al., 1997; Karg, 1998; Halstead and Tierney, 1998; Rosen 2005; Delhon et al., 2008; Tsartsidou et al., 2008).

Conversely, penning deposits from Sp. 630 in the North Area display a phytolith component dominated by grasses, suggesting that leaves and culms of grasses and reeds may have been used as fodder/ or grazed, and perhaps also as bedding. The presence of Pooideae grasses and reed multi-celled phytoliths, in association with other silica biofossils such diatoms and sponge spicules that are indicators of well-watered 
conditions, suggest the exploitation of local wetland environments. Further, previous micromorphological observations of siliceous plant remains from penning deposits at Sp.199 and Sp. 198 in the early phases of the settlement, also suggested that herbivore diet included reeds (Matthews et al., 1996; Matthews, 2005), pointing to the important role of these wild plants through time. Overall, these differential vegetal compositions attest highly variable plant diets amongst the herbivores penned within the settlement at Catalhoyuk and foddering practices, although with an important input of grasses and reeds. This is consistent with combined microwear and isotopic evidence from sheep teeth, which suggests a diet that included dry, mature grasses, hay fodder, cereal stubble or cereal fodder dominated by $\mathrm{C}_{3}$ fibre-rich elements, while $\mathrm{C}_{4}$ fibre-rich plants contributed only to a small dietary component. These results have contributed to tracing seasonal management of domestic herds, and suggest that some most likely grazed on winter pastures or wetland edge grasses, reeds or sedges (Henton 2012). In support of these conclusions, isotope signatures suggest that the inclusion of $\mathrm{C}_{4}$ plants may be related to foddering practices or result from moving caprines away from their natural habitat and onto the steppe/wetland mosaic and riverine and marshy areas, therefore closer to human habitation than the hill zones to provide easier access and control (Henton 2012; Middleton, 2018).

Another significant trend is the change in use of space and activity in the South Area, from a long history of open area/ midden use to penning of herbivorous animals at the end of the earliest occupation observed in Sp. 620, and particularly in Sp. 199 and Sp.198 (Matthews, 2005; Cessford, 2007). Further, the successive penning areas suggest greater proximity to and management of herds within the boundaries of the site that would have contributed to the viability of early settled life. The intensity of penning activity, attested by several penning areas and accumulations of compacted animal dung, indicate local management and protection of herd resources within the settlement immediately prior to a phase of settlement expansion and access to wider networks and resources, which was likely supported at least in part by access to livestock and their products (Matthews, 2018). The presence of animal pens within the settlement in its earlier occupation, provide direct evidence of the proximity of humans and animals and patterns of co-habitation. In addition, these results contribute to our current understanding of foddering practices and animal management strategies during the 
Neolithic, with critical implications regarding the organisation of space and health for early settled life-ways and the spread of zoonotic diseases.

The recently discovered animal enclosure in $\mathrm{Sp}$. 630, in the North Area, represents further evidence of livestock penning with important implications for the investigation of early domestication, animal diet and herd management preceding major settlement re-organisation (Anderson et al., 2017). It represents the only direct evidence of penning found in the North Area of the site to date, where much of the settlement comprises buildings and open/midden areas. In addition to micromorphological evidence, biomolecular signatures from suspected dung deposits in middens and other contexts from different areas at the site, revealed the relative lack of ruminant faeces and the predominance of human coprolites (Shillito et al., 2011). These patterns support previous zooarchaeological and isotopic evidence that herds were kept away from the settlement throughout much of the site occupation, with evidence to suggest that this was at increasing distances later in the history of the settlement (Roberts and Rosen, 2009; Henton, 2012; Boogard et al., 2014; Middleton, 2018; García-Suárez et al., 2018). Livestock management strategies would have entailed a significant increase in the mobility of both humans and herds, as suggested by skeletal, faunal, and isotopic evidence from the later levels of occupation at the East Mound, which appear to indicate increased exploitation of the wider landscape (Pearson et al., 2007, 2015; Pearson, 2013; Russell et al., 2013; Spencer Larsen et al., 2013; Middleton, 2018). Overall, these patterns represent changing relationships between people and livestock and on the socio-economic and ecological associations at a time when the settlement was becoming less compact and more open.

\section{Conclusions}

Integrated geoarchaeological and archaeobotanical evidence from open areas at Çatalhöyük East have provided direct evidence from animal penning and highlighted how these are important archaeological data sets and contexts in which to explore continuity and change in the animal management strategies developed by early Neolithic communities. Most of the identified penning areas of the site are located in the early phases of occupation of the South Area of the East Mound, with only one example found in the North Area, demonstrating the management of animals in pens within the boundaries of the site from $c a$. 7000- $6650 \mathrm{cal} \mathrm{BC}$. These findings need to be evaluated 
in their wider socio-economic and ecological context as key transitional points in the use of the space and re-organisation of the settlement. The research reported here also sheds new light on highly variable diets amongst herbivorous animals at the site, including both leafy and grass-based foddering/grazing regimes, although with an important input of the later plants through the lifetime of the settlement. Furthermore, it illustrates patterns of co-habitation of humans with animals, their food and their dung. The presence of animal pens within the settlement indicates an intimate association between humans and herds and provides direct evidence for early animal management, foddering practices and ecology, with important implications regarding the organization of the space and health conditions for early settled life.

\section{Acknowledgments}

The study was carried out within the framework of the Çatalhöyük Research Project, the John Templeton Foundation Grant Consciousness and Creativity and the Dawn of Settled Life: The Test-case of Çatalhöyük (award No 52003), and EU Horizon 2020 MICROARCHEODUNG project. This project has received funding from the European Union's Horizon 2020 research and innovation programme under the Marie Sklodowska-Curie grant agreement No H2020-MSCA-IF-2015-702529. We are grateful to all the Çatalhöyük team members and to the project Director Ian Hodder for their helpful discussions and support, particularly to Cristina Belmonte, Jason Quinlan, Alex Bayliss, Justine Issavi, Dorian Q. Fuller, Lara González Carretero, Ceren Kabukcu, Kamilla Pawłowska, David Orton, Dominik Lukas, and Bilge Kucukdoğan, as well as to the Directorate of Antiquities and Heritage and the Turkish Ministry of Culture and Tourism and its representatives for permission to export the sediment samples and conduct this research at Çatalhöyük. We are also grateful to Ann-Marie Catten and Kate Dudgeon, who helped in the phytolith laboratory at the University of Reading.

\section{References}

Abell, J.T., Quade, J., Duru, G., Mentzer, S.M., Stiner, M.C., Uzdurum, M., Özbaşaran, M. 2019. Urine salts elucidate Early Neolithic animal management at Aşıklı Höyük, Turkey. Scientific Advances 5, eaaw0038.

Albert, R.M., Weiner, S., 2001. Study of phytoliths in prehistoric ash layers using a quantitative approach. In: Meunier, J.D., Colin, F. (Eds.), Phytoliths, Applications in Earth Sciences and Human History. A.A. Balkema Publishers, Lisse, pp. 251-266. 
Albert, R.M., Shahack-Gross, R., Cabanes, D., Gilboa, A., Lev-Yadun, S., Portillo, M., Sharon, I., Boaretto, E., Weiner S., 2008. Phytolith-rich Layers from the Late Bronze and Iron Ages at Tel Dor (Israel): Mode of Formation and Archaeological Significance. Journal of Archaeological Science 35, 57-75.

Albert, R.M., Ruiz, J.A. Sans, A., 2016. PhytCore ODB: a new tool to improve efficiency in the management and exchange of information on phytoliths. Journal of Archaeological Science 68, 98-105.

Anderson, D.G., Lovers, J.P.L., Schoer, S.A., Wishart, R.P., 2017. Architectures of domestication: on emplacing human-animal relations in the North. Journal of the Royal Anthropological Institute23, 398-418.

Anderson, S., Ertuğ-Yaraş F., 1998. Fuel fodder and faeces: an ethnographic and botanical study of dung fuel use in central Anatolia. Environmental Archaeology 1, 99110.

Angelucci D.E., Boschian G., Fontanals M., Pedrotti, A., Vergès J.M., 2009.Shepherds and karst: the use of caves and rock-shelters in the Mediterranean region during the Neolithic. Word Archaeology 41, 191-214.

Asouti, E., 2005. Woodland vegetation and the exploitation of fuel and timber at Neolithic Çatalhöyük: report on the wood-charcoal macro-remains. In: Hodder, I. (Ed.), Inhabiting Çatalhöyük, Reports from the 1995-1999 seasons. McDonald Institute for Archaeological Research, Cambridge, and British Institute at Ankara, London, pp. 213260.

Asouti, E., 2013. Woodland vegetation, firewood management and woodcrafts at Neolithic Çatalhöyük. In: Hodder, I. (Ed.), Humans and Landscapes of Çatalhöyük: Reports from the 2000-2008 Seasons. Cotsen Institute of Archaeology Press, Los Angeles, pp. 129-162.

Atalay, S., Hastorf, C.A., 2006. Food, meals, and daily activities: food habitus at Neolithic. American Antiquity 71, 283-319.

Ayala, G., Wainwright, J. Walker, J. Hodara, R., Lloyd, J.M., Leng, M., Doherty. C., 2017. Palaeoenvironmental reconstruction of the alluvial landscape of Neolithic Çatalhöyük, central southern Turkey: The implications for early agriculture and responses to environmental change. Journal of Archaeological Science 87, 30-43.

Baird, D.. 2014. Origins of caprine herding. Proceedings of the National Academy of Sciences 111, 8702 .

Baird, D., Fairbairn, A., Jenkins, E., Martin, L., Middleton, C., Pearson, J., Asouti, E., Edwards, Y., Kabukcu, C., Mustafaoğlu, G., Russell, N., Bar-Yosef, O., Jacobsen, G., $\mathrm{Wu}, \mathrm{X}$., Baker, A., Elliott, S., 2018. Agricultural origins on the Anatolian plateau. Proceedings of the National Academy of Sciences 115 (14), e3077. 
Bayliss, A., Brock, F., Farid, S., Hodder, I., Southon, J., Taylor, R.E., 2015. Getting to the bottom of it all: a Bayesian approach to dating the start of Çatalhöyük. Journal of World Prehistory 28, 1-26.

Bogaard, A., Charles, M., Livarda, A., Ergun, M., Filipović, D., Jones, G., 2013. Archaeobotany of the mid-later occupation levels at Neolithic Çatalhöyük. In: Hodder I. (Ed.), Humans and landscapes of Çatalhöyük: reports from the 2000-2008 seasons. Monographs of the Cotsen Institute of Archaeology, Los Angeles, pp. 93-129.

Bogaard, A., Henton, E., Evans, J.A., Twiss, K.C., Charles, M.P., Vaiglova, P., Russell, N., 2014. Locating land use at Neolithic Çatalhöyük, Turkey: the implications of ${ }^{87} \mathrm{Sr} /{ }^{86} \mathrm{Sr}$ signatures in plants and sheep tooth sequences. Archaeometry 56, 860-877.

Bogaard, A., Filipović, D., Fairbairn, A., Green, L., Stroud, E., Fuller, D.Q., Charles, M. 2017. Agricultural innovation and resilience in a long-lived early farming community: the 1500-year sequence at Neolithic-early Chalcolithic Çatalhöyük, central Anatolia. Anatolian Studies 67, 1-28.

Boyer, P., Roberts, N., Baird, D., 2006. Holocene environment and settlement on the Çarşamba alluvial fan, South-Central Turkey: Integrating Geoarchaeology and Archaeological Field Survey. Geoarchaeology 21, 675-698.

Brochier, J.E., Villa, P., Giacomarra, M., Tagliacozzo, A., 1992. Shepherds and sediments: geo-ethnoarchaeology of pastoral sites. Journal of Anthropological Archaeology 11, 47-102.

Brönnimann, D., Ismail-Meyer, K., Rentzel, P., Pümpin, C., Lisá, L. 2017. Excrements of herbivores. In: Nicosia, C., Stoops, G. (Eds.), Archaeological Soil and Sediment Micromorphology. John Wiley and Sons Ltd., Oxford, pp. 55-65.

Brown, D.A., 1984. Prospects and limits of a phytolith key for grasses in the central United States. Journal of Archaeological Science11, 345-368.

Bull, I. D., Elhmmali, M. M., Perret, V., Matthews, W., Roberts, D. J., Evershed, R.P., 2005. Biomarker evidence of faecal deposition in archaeological sediments at Çatalhöyük. In: Hodder, I. (Ed.), Inhabiting Çatalhöyük: Reports from the 1995-1999 Seasons. McDonald Institute for Archaeological Research, Cambridge, pp. 415-420.

Cabanes D., Burjachs F., Expósito I., Rodríguez A., Allué E., Euba I., Vergès J.M., 2009. Formation processes through archaeobotanical remains: The case of the Bronze Age levels in El Mirador cave, Sierra de Atapuerca, Spain. Quaternary International 193, 160-173.

Cabanes, D., Weiner, S., Shahack-Gross, R., 2011. Stability of phytoliths in the archaeological record: a dissolution study of modern and fossil phytoliths. Journal of Archaeological Science 38, 2480-2490.

Canti, M.G., 1999. The production and preservation of faecal spherulites: Animals, environment and taphonomy. Journal of Archaeological Science 26, 251-258. 
Canti, M.G., Nicosia, C., 2018 Formation, morphology and interpretation of darkened faecal spherulites. Journal of Archaeological Science 89, 32-45.

Cessford, C. 2007. Level Pre-XII.E-A and Levels XII and XI Spaces 181, 199 and 198. In: Hodder, I. (Ed.), Excavating Çatalhöyük. South, North and KOPAL Area reports from the 1995-99 seasons. McDonald Institute for Archaeological Research, Cambridge, and British Institute at Ankara, London, pp. 59-102.

Coil, J., Korstanje M.A., Archer, S., Hastorf, C.A., 2003. Laboratory goals and considerations for multiple microfossil extraction in archaeology. Journal of Archaeological Science 30, 991-1008.

Courty, M.A., Macphail, R.I., Wattez, J. 1991. Soil micromorphological indicators of pastoralism: with special reference to Arene Candide, Finale Ligure, Italy. Rivista di Studi Liguri 57 (1-4), 127-150.

Charles, M., Doherty, C., Asouti, E., Bogaard, A., Henton, E., Spencer Larsen, C., Ruff, C.B., Ryan, P., Sadvari, J.W. Twiss, K.C. 2014. Landscape and taskscape at Çatalhöyük: an integrated perspective. In: Hodder, I. (Ed.), Humans and Landscapes of Çatalhöyük: Reports from the 2000-2008 Seasons. Cotsen Institute of Archaeology Press, Los Angeles, pp. 71-90.

Dalton, M., Ryan, P., 2018. Variable ovicaprid diet and faecal spherulite production at Amara West, Sudan. Environmental Archaeology,https://doi.org/10.1080/14614103.2018.1501852

Delhon C., Martin L., Argant J., Thiébault, S., 2008. Shepherds and plants in the Alps: multi-proxy archaeobotanical analysis of neolithic dung from "La Grande Rivoire" (Isère, France). Journal of Archaeological Science 35, 2937-2952.

Delhon, C., Binder, D., Verdin, P., Mazuy, A. 2019. Phytoliths as a seasonality indicator? The example of the Neolithic site of Pendimoun, south-eastern France. Vegetation History and Archaeobotany. doi: 10.1007/s00334-019-00739-0

Di Lernia, S. 2001. Dismantling Dung: Delayed Use of Food Resources among Early Holocene Foragers of the Libyan Sahara. Journal of Anthropological Archaeology 20, 408-411.

Dunseth, Z.C., Shahack-Gross, R.. 2018. Calcitic dung spherulites and the potential for rapid identification of degraded animal dung at archaeological sites using FTIR spectroscopy. Journal of Archaeological Science 97, 118-124.

Égüez, N., Makarewicz, Ch.A., 2018. Carbon isotope ratios of plant $n$-alkanes and microstratigraphy analyses of dung accumulations in a pastoral nomadic winter campsite (eastern Mongolia). Ethnoarchaeology 10, 141-158.

Égüez, N., Zerboni, A., Biagetti, B., 2018. Microstratigraphic analysis on a modern central Saharan pastoral campsite. Ovicaprine pellets and stabling floors as 
ethnographic and archaeological referential data. Quaternary International 483, 180193.

Elliott, S., Bendrey, R. Whitlam, J. Rauf Aziz, K., Evans, J., 2015. Preliminary ethnoarchaeological research on modern animal husbandry in Bestansur, Iraqi Kurdistan: Integrating animal, plant and environmental data. Environmental Archaeology 20, 283-303.

Evershed, R.P., Payne, S., Sherratt, A.G., Copley, M.S., Coolidge, J., Urem-Kotsu, D., Kotsakis, K., Ozdogan, M., Ozdogan, A.E., Nieuwenhuyse, O., P.M.M.G. Akkermans, D. Bailey, Andeescu, R.R., Campbell, S., Farid, S., Hodder, I., Yalman, N., Ozbasaran, M., Bicakci, E., Garfinkel, Y., Levy, T., Burton, M.M., 2008. Earliest date for milk use in the Near East and southeastern Europe linked to cattle herding. Nature 455 (7212), $528-531$.

Fairbairn, A., Asouti, E., Near, J., Martinoli, D., 2002. Macro-botanical evidence for plant use at Neolithic Çatalhöyük south-central Anatolia, Turkey. Vegetation History Archaeobotany 11, 41-54.

Fairbairn, A., Near, J., Martinoli, D., 2005. Macrobotanical investigation of the North, South, and Kopal Area Excavations. In: Hodder, I. (Ed.), Inhabiting Çatalhöyük, Reports from the 1995-99 Seasons. McDonald Institute for Archaeological Research, Cambridge, and British Institute at Ankara, London, pp. 137-202.

Farid, S., 1997. Mellaart Area. Çatalhöyük 1997 Archive Report. http://www.catalhoyuk.com/archive_reports/1997.

Farid, S., 2007. Level IX relative heights, Building 2, Buildings 22 and 16 and Building 17. In: Hodder, I. (Ed.), Excavating Çatalhöyük. South, North and KOPAL Area reports from the 1995-99 seasons. McDonald Institute for Archaeological Research, Cambridge, and British Institute at Ankara, London, pp. 139-226.

Filipović, D., 2014. Early farming in Central Anatolia: an archaeobotanical study of crop husbandry, animal diet and land use at Neolithic Çatalhöyük. BAR International Series 2667, Archaeopress, Oxford.

Fırıncıoğlu, H.K., Seefeldt, S.S., Şahin, B., 2007. The effects of long-term grazing exclosures on range plants in the central Anatolian region of Turkey. Environmental Management 39, 326-337.

García-Suárez A., Portillo, M., Matthews, W., 2018. Early animal management strategies during the Neolithic of the Konya Plain, Central Anatolia: integrating micromorphological and microfossil evidence. Environmental Archaeology, https://doi.org/10.1080/14614103.2018.1497831.

García-Suárez, A., Matthews, W., Portillo, M., Forthcoming. Micromorphology: exploring micro-contextual traces of settled life at Çatalhöyük. In: I. Hodder (Ed.), The environment and economy of Çatalhöyük East Mound based on the excavations 20092017, Çatalhöyük Research Project Volume 16. 
González Carretero L., Wollstonecroft, M., Fuller, D.Q., 2017. A methodological approach to the study of archaeological cereal meals: a case study at Çatalhöyük East (Turkey). Vegetation History Archaeobotany 26, 415-432.

Halstead, P., Tierney, J., 1998. Leafy hay: an ethnoarchaeological study in NW Greece. Environmental Archaeology 1, 71-80.

Henton, E., 2012. The combined use of oxygen isotopes and microwear in sheep teeth to elucidate seasonal management of domestic herds: the case study of Çatalhöyük, Central Anatolia. Journal of Archaeological Science 39, 3264-3276.

Hodder, I., 2006. The Leopard's Tale. Thames \& Hudson, London.

Hodder, I., 2007. Çatalhöyük in the Context of the Middle Eastern Neolithic. Annual Review of Anthropology 36, 105-120.

Hodder, I., 2013. From diffusion to structural transformation: the changing roles of the Neolithic house in the Middle East, Turkey and Europe. In: Hofmann D., Smyth J. (Eds.), Counterpoint: essays in archaeology and heritage studies. Archaeopress, Oxford, pp. 349-362.

Jones, G., Valamoti, S.M., Charles, M., 2000. Early crop diversity: a "new" glume wheat from northern Greece. Vegetation History Archaeobotany 9, 133-146.

Kabukcu, C., 2018. Identification of woodland management practices and tree growth conditions in archaeological fuel waste remains: A case study from the site of Çatalhöyük in central Anatolia, Turkey. Quaternary International 463, 282-297.

Karg S. 1998. Winter- and Spring-foddering of Sheep/Goat in the Bronze Age Site of Fiavè-Carera, Northern Italy. Environmental Archaeology 1, 87-94.

Karkanas, P., 2006. Late Neolithic household activities in marginal areas: the micromorphological evidence from the Kouveleiki caves, Peloponnese, Greece. Journal of Archaeological Science 33, 1628-1641.

Katz, O., Cabanes, D. Weiner, S., Maeir, A., Boaretto, E., Shahack-Gross, R., 2010. Rapid phytolith extraction for analysis of phytolith concentrations and assemblages during an excavation: An application at Tell es-Safi/Gath, Israel. Journal of Archaeological Science 37, 1557-1563.

Klimowicz, A., 2017. Building 132, Spaces 633 and 531 and underlying external area Space 630. Çatalhöyük 2017 Archive Report, pp. 1930.http://www.catalhoyuk.com/archive reports/2017.

Korstanje, M.A., 2005. Microfossils in camelid dung: Taphonomic considerations for the archaeological study of agriculture and pastoralism. In: O'Connor, T. (Ed.), Biosphere to Lithosphere: New Studies in Vertebrate Taphonomy. Oxbow Books, Oxford, pp. 69-77. 
Macphail, R.I., Courty, M.A., Hartner, J., Wattez, J., 1997. The soil micromorphological evidence of domestic occupation and stabling activities. In: Maggi, R. (Ed.), Arene Candide: A Functional and Environmental Assessment of the Holocene Sequences Excavated by Bernardo Brea (1940-1950). Istituto Italiano di Paleontologia Umana, Rome, pp. 53-88.

Macphail R.I., Cruise, G.M., Allen, M.J., Linderholm, J., Reynolds, P., 2004 Archaeological soil and pollen analysis of experimental floor deposits; with special reference to Butser ancient farm, Hampshire, UK. Journal of Archaeological Science $31,175-191$.

Martin L., Russell N. 2000. Trashing rubbish. In: Hodder, I. (Ed.), Towards reflexive method in archaeology: the example at Çatalhöyük, McDonald Institute Monographs and British Institute of Archaeology, Cambridge, pp. 57-69.

Matthews, W., 2005. Micromorphological and microstratigraphic traces of uses of space. In: Hodder I. (Ed.), Inhabiting Çatalhöyük: Reports from the 1995-99 Seasons. MacDonald Institute for Archaeological Research and British Institute of Archaeology at Ankara, Cambridge, pp. 355-398.

Matthews, W., 2018. Creating settled life: Micro-histories of community, ritual and place - the Central Zagros and Çatalhöyük. In: Hodder, I. (Ed.), Religion History and Place: The Origins of Settled Life. University of Colorado Press, Denver, pp. 64-98.

Matthews, W., Portillo, M., 2017. Built Environment and Livestock Dung: Integrated Micromorphology, Phytolith and Chemical Analyses. Çatalhöyük 2017 Archive Report, pp. 343-352.http://www.catalhoyuk.com/archive_reports/2017.

Matthews, W., French, C., Lawrence, T., Cutler, D.F., 1996. Multiple surfaces: the micromorphology. In: Hodder, I. (Ed.), On the Surface Çatalhöyük 1993-95. McDonald Institute for Archaeological Research/BIAA, Cambridge, pp. 301-342.

Matthews, W., Shillito, L.,-M., Elliott, S. 2014. Neolithic lifeways: microstratigraphic traces within houses, animal pens and settlements. In: Whittle, A., Bickle, P. (Eds.), Early Farmers: The View from Archaeology and Science. Oxford University for The British Academy, Oxford, pp. 251-279.

Mellaart, J., 1967. Çatalhöyük: A Neolithic Town in Anatolia. Thames \& Hudson, London.

Middleton, C., 2018. The beginning of herding and animal management: the early development of caprine herding on the Konya plain, central Anatolia. Anatolian Studies68, 1-31.

Milek, K., 2012. Floor formation processes and the interpretation of activity areas: an ethnoarchaeological study of turf buildings at Thverá, northeast Iceland. Journal of Anthropological Archaeology 31, 119-137. 
Mulholland, S.C., Rapp Jr.G., 1992. A morphological clasification of grass silicabodies. In: Rapp, G.Jr., Mulholland, S.C (Eds.), Phytolith Systematics: Emerging Issues, Advances in Archaeological and Museum Science. Plenum Press, New York, pp. 65-89.

Neumann, K., Strömberg, A.E.C., Ball, T., Albert, R.M., Vrydaghs, L. ScottCummings, L. (International Committee for Phytolith Taxonomy ICPT). 2019. International Code for Phytolith Nomenclature (ICPN) 2.0. Annals of Botany. doi:10.1093/aob/mcz064.

Orton, D., Anvari, J., Gibson, C., Last, J., Bogaard, A., Rosenstock, E., Biehl, P.F. 2018. A tale of two tells: dating the Çatalhöyük West Mound. Antiquity 92 (363), 620639.

Pawłowska, K., 2014. The smells of Neolithic Çatalhöyük, Turkey: Time and space of human activity. Journal of Anthropological Archaeology 36, 1-11.

Pearson, J.A., 2013. Human and animal diet as evidenced by stable carbon and nitrogen isotope analysis. In: Hodder, I. (Ed.), Humans and Landscapes of Çatalhöyük: Reports from the 2000-2008 Seasons. Cotsen Institute of Archaeology Press, Los Angeles, pp. 271-298.

Pearson, J.A., Buitenhuis, H., Hedges, R.E.M., Martin, L., Russell, N., Twiss, K. C., 2007. New light on early caprine herding strategies from isotope analysis: a case study from Neolithic Anatolia. Journal of Archaeological Science 34, 2170-2179.

Pearson, J.A., Bogaard, A., Charles, M., Hillson, S.W., Spencer Larsen, C., Russell, N., Twiss, K.. 2015. Stable carbon and nitrogen isotope analysis at Neolithic Çatalhöyük: evidence for human and animal diet and their relationship to households. Journal of Archaeological Science 57, 69-79.

Piperno, D.R., 1988. Phytolith Analysis: An Archaeological and Geological Perspective. Academic Press, San Diego.

Piperno, D.R., 2006. Phytoliths: A comprehensive Guide for Archaeologists and Paleoecologists. Altamira Press, Lanham.

Polo-Díaz, A., Eguíluz, M., Ruiz, M., Pérez, S., Mújika, J., Albert, R.M., Fernández Eraso, J., 2016. Management of residues and natural resources at San Cristóbal rockshelter: contribution of the characterization of chalcolithic agropastoral groups in the Iberian Peninsula. Quaternary International 414, 202-225.

Portillo, M., Albert R.M.,2011. Husbandry practices and livestock dung at the Numidian site of Althiburos (el Médéina, Kef Governorate, northern Tunisia): the phytolith and spherulite evidence. Journal of Archaeological Science 38, 3224-3233.

Portillo, M., Matthews, W. accepted. Investigating use of space and human-animal interactions in agricultural built environments: the geo-ethnoarchaeology of livestock 
dung. In: Proceedings of the 11th International Congress on the Archaeology of the Ancient Near East, Harrassowitz Verlag, Wiesbaden.

Portillo, M., García-Suárez, A., Matthews, W. accepted. Livestock faecal indicators for animal management, penning, foddering and dung use in early agricultural built environments in the Konya Plain, Central Anatolia. Archaeological and Anthropological Sciences.

Portillo, M., Albert R.M., Henry, D.O., 2009. Domestic activities and spatial distribution in Ain Abū Nukhayla (Wadi Rum, Southern Jordan): The use of phytoliths and spherulites studies. Quaternary International 193, 174-183.

Portillo, M., Valenzuela, S., Albert R.M., 2012. Domestic patterns in the Numidian site of Althiburos (northern Tunisia): the results from a combined study of animal bones, dung and plant remains. Quaternary International 275, 84-96.

Portillo, M., Kadowaki, S., Nishiaki, Y., Albert, R.M. 2014. Early Neolithic household behavior at Tell Seker al-Aheimar (Upper Khabur, Syria): a comparison to ethnoarchaeological study of phytoliths and dung spherulites. Journal of Archaeological Science 42, 107-118.

Portillo, M., Belarte, M.C., Ramon, J. Kallala, N. Sanmartí, J., Albert, R.M., 2017. An ethnoarchaeological study of livestock dung fuels from cooking installations in northern Tunisia. Quaternary International 431, 133-44.

Prost, K., Birk, J.J., Lehndorff, E., Gerlach, R., Amelung, W., 2017. Steroid biomarkers revisited- improved source identification of faecal remains in archaeological soil material. PLoS One 12 (1), e0164882.

Rasmussen P., 1989. Leaf-foddering of Livestock in the Neolithic: Archaeobotanical Evidence fromWeier, Switzerland. Journal of Danish Archaeology 8, 51-71.

Rasmussen, P., 1993. Analysis of sheep/goat faeces from Egolzwil 3, Switzerland: evidence for branch and twig foddering of livestock in the Neolithic. Journal of Archaeological Science 20, 479-502.

Roberts, N., Rosen A.M., 2009. Diversity and complexity in early farming communities of Southwest Asia: new insights into the economic and environmental basis of Neolithic Çatalhöyük. Current Anthropology 50, 393-402.

Roberts, N., Boyer, P., Parish, R., 1996. Preliminary results of geoarcheological investigations at Çatalhöyük. In: Hodder, I. (Ed.), On the Surface Çatalhöyük 1993-95. McDonald Institute for Archaeological Research/BIAA, Cambridge, pp.19-40.

Roberts, N., Black, S., Boyer, P., Eastwood, W.J., Griffiths, H.I., Lamb, H.F., Leng, M.J., Parish, R., Reed, J.M., Twigg, D., Yiğitbaşioğlu, H., 1999. Chronology and stratigraphy of Late Quaternary sediments in the Konya Basin, Turkey: Results from the KOPAL project. Quaternary Science Reviews 18, 611-630. 
Rosen, A.M., 1992. Preliminary identification of silica skeletons from Near Eastern archaeological sites: an anatomical approach. In: Rapp, G.Jr., Mulholland, S.C (Eds.), Phytolith Systematics: Emerging Issues, Advances in Archaeological and Museum Science. Plenum Press, New York, pp. 129-148.

Rosen, A.M., 2005. Phytolith indicators of plant and land use at Çatalhöyük. In: Hodder, I. (Ed.), Inhabiting Çatalhöyük, Reports from the 1995-99 Seasons. McDonald Institute for Archaeological Research Cambridge, and British Institute at Ankara, London, pp. 203-212.

Russell, N., Martin, L., 2005. Çatalhöyük mammal remains. In: Hodder, I. (Ed.), Inhabiting Çatalhöyük, Reports from the 1995-99 Seasons. McDonald Institute for Archaeological Research Cambridge, and British Institute at Ankara, London, pp. 3398.

Russell N., Martin L., 2012. Cooking meat and bones at Neolithic Çatalhöyük, Turkey. In: Graff S.R., Rodríguez-Alegría, E. (Eds.), The menial art of cooking: archaeological studies of cooking and food preparation. University Press of Colorado, Colorado, pp. 87-93.

Russell, N., Martin, L., Buitenhuis, H., 2005. Cattle domestication at Çatalhöyük revisited. Current Anthropology 46, 101-108.

Russell, N., Martin, L., Twiss, K.C., 2009. Building memories: commemorative deposits at Çatalhöyük. Anthropozoologica 44, 103-128.

Russell, N., Twiss, K. C., Orton, D.C., Arzu Demirergi, G., 2013. More on the Çatalhöyük mammal remains. In: Hodder, I. (Ed.), Humans and Landscapes of Çatalhöyük: Reports from the 2000-2008 Seasons. Cotsen Institute of Archaeology Press, Los Angeles, pp. 213-258.

Ryan, P., 2011. Plants as material culture in the Near Eastern Neolithic: perspectives from the silica skeleton artifactual remains at Çatalhöyük. Journal of Anthropological Archaeology 30, 292-305.

Schepers, M., Van Haaster, H., 2015. Dung matters: An experimental study into the effectiveness of using dung from hay-fed livestock to reconstruct local vegetation. Environmental Archaeology 20, 66-81.

Schwandes, L.P. Collins M.E. 1994. Distribution and significance of freshwater sponge spicules in selected Florida soils. Transactions of the American Microscopical Society $113,242-257$.

Shahack-Gross, R., 2011. Herbivorous livestock dung: formation, taphonomy, methods for identification, and archaeological significance. Journal of Archaeological Science 38, 205-218. 
Shahack-Gross, R., 2017. Animal gathering enclosures. In: Nicosia, C., Stoops, G. (Eds.), Archaeological Soil and Sediment Micromorphology. John Wiley \& Sons, Chichester, pp. 265-280.

Shahack-Gross, R., Finkelstein, I. 2008. Subsistence practices in an arid environment: a geoarchaeological investigation in an Iron Age site, the Negev Highlands. Israel. Journal of Archaeological Science 35, 965-982.

Shahack-Gross, R., Marshall, F., Weiner, S., 2003. Geo-ethnoarchaeology of pastoral sites: the identification of livestock enclosures in abandoned Maasai settlements. Journal of Archaeological Science 30, 439-459.

Shahack-Gross, R., Marshall, F., Ryan, K., Weiner, S., 2004. Reconstruction of spatial organization in abandoned Maasai settlements: implications for site structure in the pastoral Neolithic of East Africa. Journal of Archaeological Science 31, 1395-1411.

Shillito, L.-M., 2011. Simultaneous thin section and phytolith observations of finely stratified deposits from Neolithic Çatalhöyük, Turkey: implications for paleoeconomy and Early Holocene paleoenvironment. Journal of Quaternary Science 26, 576-588.

Shillito, L.-M., 2017. Multivocality and multiproxy approaches to the use of space: lessons from 25 years of research at Catalhoyuk. World Archaeology 49, 237-259.

Shillito, L.-M., Matthews, W., 2013. Geoarchaeological investigations of midden-formation processes in the Early to Late ceramic Neolithic levels at Çatalhöyük, Turkey ca. 8550-8370 cal BP. Geoarchaeology 28, 25-49.

Shillito, L.-M., Matthews, W., Bull, I. D., Almond, M. J., Williams, J. M., Evershed, R. P., 2013. Integrated geochemical and microscopic analysis of human coprolites, animal dung and organic remains in burials. In: Hodder, I. (Ed.), Humans and Landscapes of Çatalhöyük: Reports from the 2000-2008 Seasons. Cotsen Institute of Archaeology Press, Los Angeles, pp. 75-78.

Shillito, L.-M., Matthews, W., Almond, M.J., 2008. Investigating midden formation processes and cultural activities at Neolithic Çatalhöyük, Turkey. Antiquity 82.

http://antiquity.ac.uk/projgall/shillito317/.

Shillito, L.-M., Bull, I.D., Matthews, W., Almond, M.J., Williams, J.M., Evershed, R.P., 2011. Biomolecular and micromorphological analysis of suspected faecal deposits at Neolithic Çatalhöyük, Turkey. Journal of Archaeological Science 38, 1869-1877.

Spencer Larsen, C., Hillson, S.W., Ruff, C.B., Sadvari, J.W., Garofalo, E.M., 2013. The human remains II: interpreting lifestyle and activity in Neolithic Çatalhöyük. In: Hodder, I. (Ed.), Humans and Landscapes of Çatalhöyük: Reports from the 2000-2008 Seasons. Cotsen Institute of Archaeology Press, Los Angeles, pp. 397-412.

Spengler, R.N., 2018. Dung burning in the archaeobotanical record of West Asia: where are we now? Vegetation History and Archaeobotany, https://doi.org/10.1007/s00334018-0669-8. 
Stiner, M.C., Buitenhuis, H., Duru, G., Kuhn, S.L., Mentzer, S.M, Munro, N.D, Pöllath, N., Quade, J., Tsartsidou, G., Özbaşaran, M.. 2014. A forager-herder trade-off, from broad-spectrum hunting to sheep management at Aşıklı Höyük, Turkey. Proceedings of the National Academy of Sciences 111 (23), 8404-8409.

Stoops, G., 2003. Guidelines for Analysis and Description of Soil and Regolith Thin Sections. Soil Science Society of America, Madison, Wisconsin.

Taylor, J. 2017. Excaations in the South Area. Çatalhöyük 2017 Archive Report, pp. 63-82.http://www.catalhoyuk.com/archive reports/2017.

Tsartsidou, G., Lev-Yadun, S., Albert, R., Rosen, A.M., Efstratiou, N., Weiner, S., 2007. The phytolith archaeological record: strengths and weaknesses evaluated based on a quantitative modern reference collection from Greece. Journal of Archaeological Science $34,1262-1275$.

Tsartsidou, G., Lev-Yadun, S., Efstratiou, N., Weiner, S., 2008. Ethnoarchaeological study of phytolith assemblages from an agro-pastoral village in Northern Greece (Sarakini): development and application of a Phytolith Difference Index. Journal of Archaeological Science 35, 600-613.

Twiss, P.C., 1992. Predicted world distribution of $\mathrm{C}_{3}$ and $\mathrm{C}_{4}$ grass phytoliths. In:Rapp, G.Jr., Mulholland, S.C (Eds.), Phytolith Systematics: Emerging Issues, Advances in Archaeological and Museum Science. Plenum Press, New York, pp. 113-128.

Twiss, P.C., Suess, E., Smith, R.M., 1969. Morphological classification of grass phytoliths. Soil Science Society of America Proceedings 33, 109-115.

Wilding L.P., Drees L.R., 1971. Biogenic opal in Ohio soils. Proceedings of the Soil Science Society of America 35, 1004-1010.

Zeder, M.A., 2005. A view from the Zagros: new perspectives on livestock domestication in the Fertile Crescent. In: Vigne, J.D., Peters, J., Helmer, D. (Eds.), First Steps of Animal Domestication. Oxbow Books, Oxford, 125-146.

\section{Figures caption}

Fig. 1. Site plan of Çatalhöyük East with main excavation areas. Detailed view of Space 630 in the North Area (top) and plan view of Sp. 620 in the South Area (bottom) showing sampling locations. Sources: C. Mazzucato for Çatalhöyük Research Project (site plan) and J. Quinlan, M.Z. Barański and J. Tripkovic (ortophotos).

Fig. 2. Synthetic diagram of the microstratigraphic sequence in sample 23214.s10 displaying the bedding and composition of each microfacies.

Fig. 3. Photomicrographs illustrating the different types of microfacies (MF) identified in Sp. 620 micromorphological samples 23214.11 (a-b-c) and 23214.10 (d-e-f): (a) 
MF1a, heterogeneous midden displaying no traces of dung, PPL; (b) MF1b, lense of trampled herbivore dung in midden matrix, PPL; (c) MF2, calcitic ashes derived from the combustion of grasses and herbivore faecal matter, XPL; (d) MF3a, trampled layers of fibrous dung showing abundant phytolith and spherulite remains, including few bright orange patches from humified/lignified organic matter, PPL; (e) MF3b, penning deposits displaying phytolith-rich dung with partially decayed spherulites and few lenses of midden materials, PPL; (f) MF3c, heavily trampled dung intermixed with calcareous sediments and midden materials, PPL (left) and XPL (right).

Fig. 4. Photomicrograph of fibrous herbivore dung displaying abundant inclusions of partially digested phytoliths (P), calcium oxalates (O) and calcitic spherulites (S), and post-depositional staining $(\mathrm{Fe})$ in the form of framboid nodules of iron (oxy) hydroxides caused by the decay of organic matter in sample 23214.11; PPL (left) and XPL (right).

Fig. 5. Photomicrographs of key components found in penning deposits from Sp. 620 samples 23214.10 (a-b-c-d-f) and 23214.11 (e): (a) stacked bulliform phytoliths derived from reeds/grasses embedded in oxidised animal dung, PPL; (b) trampled herbivore faecal matter displaying well-preserved articulated phytoliths, PPL; (c) same as b, showing abundant calcitic spherulites, XPL; (d) ferruginous impregnative pedofeatures in penning layers, PPL; (e) multicellular phytoliths in fibrous dung deposit, PPL; (f) extremely compacted upper boundary in dung layer (arrows) due to the effect of intense trampling, PPL.

Fig. 6. Photomicrographs of phytoliths and other microfossils identified in Sp. 620, 23214 samples from penning deposits $(200 \times$ or $400 \times)$. (a) Tracheary from dicotyledonous leaves, (b) epidermal base with attached appendage hair from dicotyledonous leaves, (c) bulliforms flabellate from monocotyledonous leaves, (d) articulated (multicellular) elongate phytoliths from grass leaves, (e) diatoms, (f) calcitic dung spherulites (XPL).

Fig. 7. Plot showing absolute concentrations of phytoliths $v s$. dung spherulites obtained from micromorphological block sub-samples for each of the contexts/deposit types analyzed.

Fig. 8. Photomicrographs of phytoliths and other microfossils identified in Sp. 630, 23616.s1 sub-samples from penning (a-b-c) and mixed midden deposits displaying dung lenses (d-e-f) at 400×. (a) Epidermal appendage acute bulbosus (trichome) from grass leaves, (b) grass silica short cell phytoliths (arrows sc), elongate dendritic (den) and polylobate (pol) from grasses, (c) articulated (multicellular) dendritics with short cell rondels from the husk of Pooideae grasses, (d) epidermal appendage hair base from dicotyledonous leaves, (e) melted phytoliths, (f) dung spherulites (XPL).

\section{Tables}

Table 1. Summary of excavation records and contextual field descriptions (Klimowicz, 2017; Taylor, 2017). 
Table 2. Summary of micromorphological samples with field descriptions of suspected dung deposits and micro-contextual observations.

Table 3. Location, description of samples and main quantitative phytolith and dung spherulite results obtained from spot samples (coded as s) and micromorphological block sub-samples (ss).

Table 4. Summary of the microfacies (MF) identified during the micromorphological analysis of the thin-section samples.

\section{Supplementary material}

Table S1. Location, description of samples and main phytolith results obtained from non-chemically extracted samples (coded as sne) from the South Area. A minimum of 200 phytoliths were counted at $400 \times$.

Table S2. Relative abundances of phytoliths obtained from spot samples (s) and micromorphological block sub-samples (ss). 


\section{Area/ Contextual field description}

South Open space of a total area of about 43 sqm most likely contemporary with use of 620 Building 162 which was situated directly to the east (23203 abutted the western wall of B.162). It extended to the west and south beyond the limit of excavation. The northern limit was defined by remnants of the oven F.8044 and unspecified mudbrick structure (23206). Additionally, deposits within Sp. 620 sealed midden within open Sp. 628. Oven F.8044 predates the construction of B.17 and was associated with the uppermost midden and subsequent penning deposits. The penning deposits were composed of extremely thin and laminated layers distinct in color (reddish-pink, orange and white) with a shiny superficial texture that contained orange or pinkish-white 'stains' at the basal level (23214). This appeared to be preserved better under large plastered features, including an oven with at least three distinct phases of use (F.8038) and a platform (F.21898), and was interpreted by the excavators as 'a thin layer of phytoliths and coprolites of which the preservation was extraordinarily good'. Sp. 620 was distinguished on the basis of a very distinct occupational surface that seemed to have born traces of activities related with burning and penning.

North Open space pre-dating the construction of B.132. An external character of this space $630 \quad(5.5 \mathrm{~m} \times 6.1 \mathrm{~m})$ was defined by a distinct compact trampled silty-clay surface (23616), that extended beyond the area that had been exposed. The surface 23616 appeared to be clean in terms of the artefacts and ecofacts. There was no evidence of any human activities whatsoever, except for one fragment of animal bone (23616.X1) diagnosed as Bos/Bison humerus. Although the archaeological investigations were constrained by later surrounding buildings, within its southern part it was uncovered the remains of a make-shift trapezoidal enclosure (F.8600). This enclosure was defined by narrow and badly preserved pise-like walls (23629), (23630), and (23631). The spatial arrangement of the open area consisted of accompanying features related to two post-retrieval pits (F.8349) and (F.8601). Their presence indicated a sort of light construction which must have been supported by a pair of wooden posts set vertically into the ground, suggesting a temporary shelter or shade situated to the east of the rectangular enclosure. In addition, randomly placed fire-spots observed within sections across the later intrusions complete a general overview of Sp. 630 .

Table 1. Summary of excavation records and contextual field descriptions (Klimowicz, 2017; Taylor, 2017). 


\begin{tabular}{|c|c|c|c|c|}
\hline Area & Space & Sample & Field description & Micro-context description \\
\hline South & 620 & $23214 . s 10$ & $\begin{array}{l}\text { Thin orange-brown } \\
\text { laminated layers of } \\
\text { phytoliths and coprolites }\end{array}$ & $\begin{array}{l}\text { Compacted laminated herbivore } \\
\text { dung deposits of } \sim 5 \mathrm{~cm} \text { rich in } \\
\text { calcitic spherulites and } \\
\text { dicotyledonous phytoliths from } \\
\text { animal penning }\end{array}$ \\
\hline South & 620 & 23214.s11 & $\begin{array}{l}\text { Continuous accumulation } \\
\text { of midden deposits with } \\
\text { thin orange-brown } \\
\text { laminated layers of } \\
\text { phytoliths and coprolites }\end{array}$ & $\begin{array}{l}\text { Heterogeneous midden sequence } \\
\text { with charred plant remains, } \\
\text { displaying compacted laminated } \\
\text { herbivore dung deposit of } \sim 5 \mathrm{~cm} \\
\text { rich in calcitic spherulites and } \\
\text { dicotyledonous phytoliths from } \\
\text { penning }\end{array}$ \\
\hline North & 630 & $23616 . s 1$ & $\begin{array}{l}\text { Silty-clay layer with fire- } \\
\text { spots }\end{array}$ & $\begin{array}{l}\text { Heterogeneous midden deposits } \\
\text { overlain by }>2 \mathrm{~cm} \text { of compacted } \\
\text { herbivore dung with grass/reed } \\
\text { phytoliths from penning, and } \\
\text { traces of rubefied layers from in } \\
\text { situ burning }\end{array}$ \\
\hline
\end{tabular}

Table 2. Summary of micromorphological samples with field descriptions of suspected dung deposits and micro-contextual observations. 


\begin{tabular}{|c|c|c|c|c|c|}
\hline $\begin{array}{l}\text { Unit/ } \\
\text { Sample } \\
\text { number }\end{array}$ & $\begin{array}{l}\text { Space/ } \\
\text { Building } \\
\text { (B) }\end{array}$ & $\begin{array}{l}\text { Phytoliths } \\
1 \text { g of } \\
\text { sediment } \\
\text { (million) }\end{array}$ & $\begin{array}{l}\text { Multicelled } \\
\text { phytoliths } \\
\text { (\%) }\end{array}$ & $\begin{array}{l}\text { Spherulites } \\
1 \text { g of } \\
\text { sediment } \\
\text { (million) }\end{array}$ & Description \\
\hline $23214 . s 12$ & 620 & 4.2 & 11.8 & 57.3 & Compacted dung, herbivorous penning \\
\hline 23214.s13 & 620 & 4.5 & 8.8 & 76.1 & Compacted dung, herbivorous penning \\
\hline 23214.s14 & 620 & 3.4 & 4.7 & 41.4 & Compacted dung, herbivorous penning \\
\hline 23214.s15 & 620 & 1.9 & 3 & 45.2 & Compacted dung, herbivorous penning \\
\hline $21898 . s 7$ & 620 & 2.9 & 4.7 & 9.6 & $\begin{array}{l}\text { Mixed midden deposit with burnt bone, shell } \\
\text { and dung lenses }\end{array}$ \\
\hline 23266.s1 & $\begin{array}{l}\text { B.17 wall } \\
\text { (West) }\end{array}$ & 0.4 & 3.4 & 0 & Mudbrick \\
\hline $23266 . s 2$ & $\begin{array}{l}\text { B.17 wall } \\
\text { (West) }\end{array}$ & 0.5 & 17.4 & 0 & Mortar \\
\hline 23214.s16 & 620 & 0.5 & 6.7 & 4.1 & Compacted dung, herbivorous penning \\
\hline 23214.s17 & 620 & 0.7 & 19.4 & 10.2 & Compacted dung, herbivorous penning \\
\hline 23264.s1 & 620 & 1.6 & 8.2 & 52.3 & $\begin{array}{l}\text { Compacted dung, herbivorous penning, fire- } \\
\text { spot base }\end{array}$ \\
\hline $23264 . s 2$ & 620 & 0.7 & 11.6 & 7.7 & $\begin{array}{l}\text { Mixed midden deposit with herbivorous } \\
\text { dung, fire-spot upper }\end{array}$ \\
\hline $21898 . s 5$ & 620 & 1.8 & 16.4 & 0.2 & Midden deposit rich in charred remains \\
\hline $21898 . s 6$ & 620 & 1.4 & 9.6 & 1.1 & $\begin{array}{l}\text { Midden deposit with charred bones, shells, } \\
\text { charred plants and dung }\end{array}$ \\
\hline 23265.s1 & $\begin{array}{l}\text { B.17 wall } \\
\text { (South) }\end{array}$ & 1.4 & 3.6 & 0 & Mudbrick \\
\hline 23212.s6 & 620 & 2.4 & 7.7 & 0 & Floor oven base \\
\hline 23212.s7 & 620 & 0.8 & 16.2 & 0.02 & Oven make-up \\
\hline $23215 . \mathrm{s} 7$ & 620 & 0.8 & 16.9 & 0.03 & Floor oven base \\
\hline $23216 . s 12$ & 620 & 0.5 & 11.2 & 0.02 & Floor oven base \\
\hline $23216 . s 13$ & 620 & 0.5 & 7.4 & 0.05 & Oven make-up \\
\hline 23214.s10.ss1 & $\begin{array}{l}\text { B.17 wall } \\
\text { (West) }\end{array}$ & 0.3 & 9.3 & 0.01 & Mudbrick \\
\hline 23214.s10.ss2 & $\begin{array}{l}\text { B.17 wall } \\
\text { (West) }\end{array}$ & 0.3 & 6 & 0 & Mudbrick \\
\hline 23214.s10.ss3 & 620 & 5 & 8.9 & 11.9 & Midden with trampled dung lenses \\
\hline 23214-s10-ss4 & 620 & 5 & 6.5 & 23.5 & Compacted dung, herbivorous penning \\
\hline 23214.s10.ss5 & 620 & 2.7 & 7.4 & 1.2 & Mixed midden and herbivore dung deposits \\
\hline 23214.s10.ss6 & 620 & 4.7 & 4.7 & 28.8 & Compacted dung, herbivorous penning \\
\hline 23214.s10.ss7 & 620 & 3.1 & 31.1 & 0.2 & Mixed midden with rare dung inclusions \\
\hline 23214.s11.ss1 & 620 & 2.2 & 13 & 0.2 & Midden with rare dung inclusions \\
\hline 23214.s11.ss2 & 620 & 1.6 & 12.6 & 2.8 & Mixed midden with trampled dung lenses \\
\hline 23214.s11.ss3 & 620 & 1.5 & 11.9 & 3.5 & Compacted, fibrous dung rich in phytoliths \\
\hline 23214.s11.ss4 & 620 & 6.9 & 3 & 16.5 & Compacted dung, herbivorous penning \\
\hline 23214.s11.ss5 & 620 & 2.8 & 2.8 & 3.5 & Compacted, fibrous dung rich in phytoliths \\
\hline 23214.s11.ss6 & 620 & 0.9 & 8.8 & 0.1 & Mixed midden with rare dung inclusions \\
\hline 23616.s1.ss1 & 630 & 9.3 & 13.2 & 4 & $\begin{array}{l}\text { Mixed herbivorous rich-dung lenses, fire- } \\
\text { spot }\end{array}$ \\
\hline 23616.s1.ss2 & 630 & 4.9 & 28.7 & 1.5 & Mixed herbivorous dung lenses \\
\hline
\end{tabular}




\begin{tabular}{llllll} 
23616.s1.ss3 & 630 & 2.8 & 15.4 & 0.4 & Mixed herbivorous dung lenses \\
23616.s1.ss4 & 630 & 6.4 & 10.9 & 0.8 & $\begin{array}{l}\text { In-situ burnt surface with mixed dung, burnt } \\
\text { bone and charred plant remains }\end{array}$ \\
23616.s1.ss5 & 630 & 4.9 & 7.9 & 2.1 & $\begin{array}{l}\text { Compacted dung, herbivorous penning } \\
\text { 23616.s1.ss6 }\end{array}$ \\
\hline
\end{tabular}

Table 3. Location, description of samples and main quantitative phytolith and dung spherulite results obtained from spot samples (coded as s) and micromorphological block sub-samples (ss). 


\section{MF Description}

1a Vughy midden deposits displaying a high proportion of minerogenic components, including subrounded quartz, chert, calcite and plagioclase sands, and rounded aggregates of calcareous and clayish materials. These layers also contain few subangular fragments of charred plants, ranging in size from very fine to coarse sand. No dung was identified in these units.

1b Heterogeneous midden layers containing abundant subrounded quartz and feldspar sands (fine to coarse sizes), sediment aggregates (10-20\% abundance), common heterometric fragments of charred plants, and vey few phytolith, bone, and shell inclusions. Lenses of trampled herbivore dung constitute $c a$. $10-25 \%$ of these deposits.

2 Loose, calcitic ash derived from dung and reeds/grasses, containing herbaceous phytoliths, subrounded charred plant fragments and amorphous coprolite aggregates displaying abundant decayed spherulites. Very few coarse sand-sized mineral grains and burnt sediment aggregates.

3a Fibrous phytolith- and spherulite-rich trampled dung microlaminations displaying orange staining caused by organic decay. Few interbedded lenses of trampled midden-like materials.

3b Microlaminated phytolith-rich herbivore dung displaying partially decayed spherulites. These brownish grey layers show a wavy, parallel referred orientation with respect to the upper and lower unit boundaries, an effect of intense trampling. There are few compacted lenses of minerogenic materials embedded in the dung.

3c Parallel layers formed by intermixed herbivore dung and heterogeneous midden materials showing common charred plant fragments. Few phytolith remains and absence of calcitic spherulites. Scattered subrounded sands of quartz and feldspar (medium to coarse sizes).

Table 4. Summary of the microfacies (MF) identified during the micromorphological analysis of the thin-section samples. 


\begin{tabular}{|c|c|c|c|c|c|c|}
\hline $\begin{array}{l}\text { Unit/ } \\
\text { Sample } \\
\text { number }\end{array}$ & $\begin{array}{l}\text { Space/ } \\
\text { Building } \\
\text { (B) }\end{array}$ & $\begin{array}{l}\text { Monocotyledon } \\
\text { ous } \\
\text { (\%) }\end{array}$ & $\begin{array}{l}\text { Dicotyledonous } \\
\text { leaves } \\
(\%)\end{array}$ & $\begin{array}{l}\text { Dicotyledonous } \\
\text { wood/bark } \\
(\%)\end{array}$ & $\begin{array}{l}\text { Phytoliths } \\
\text { weathering } \\
(\%)\end{array}$ & Description \\
\hline 23214.sne12 & 620 & 83 & 6.2 & 4.1 & 6.6 & Compacted dung, herbivorous penning \\
\hline 23214.sne13 & 620 & 45.3 & 44.5 & 2.7 & 7.5 & Compacted dung, herbivorous penning \\
\hline 21898.sne7 & 620 & 84.2 & 6 & 3.8 & 6 & Mixed midden deposit with burnt bone, shell and dung lenses \\
\hline 23266.sne1 & $\begin{array}{l}\text { B.17 wall } \\
\text { (West) }\end{array}$ & 85.2 & 4.1 & 2.7 & 8 & Mudbrick \\
\hline 23266.sne2 & $\begin{array}{l}\text { B.17 wall } \\
\text { (West) }\end{array}$ & 78.1 & 7.3 & 7.1 & 7.5 & Mortar \\
\hline 23214.sne16 & 620 & 75.7 & 11.5 & 4.4 & 8.4 & Compacted dung, herbivorous penning \\
\hline 23214.sne17 & 620 & 40.8 & 46.9 & 6.7 & 5.7 & Compacted dung, herbivorous penning \\
\hline 23264.sne1 & 620 & 20.8 & 49.5 & 19.6 & 10.1 & Compacted dung, herbivorous penning, fire-spot base \\
\hline 23264.sne2 & 620 & 64.8 & 12.2 & 11.6 & 11.5 & Mixed midden deposit with herbivorous dung, fire-spot upper \\
\hline 21898.sne5 & 620 & 83.4 & 6.7 & 4.3 & 5.5 & Midden deposit rich in charred remains \\
\hline 21898.sne6 & 620 & 75 & 14.4 & 7.6 & 3 & Midden deposit with charred plants and bones, shells and dung \\
\hline 23265.sne1 & $\begin{array}{l}\text { B.17 wall } \\
\text { (South) }\end{array}$ & 81.8 & 2.9 & 1.9 & 13.4 & Mudbrick \\
\hline 23212.sne6 & 620 & 79.1 & 9.3 & 6.9 & 4.7 & Floor oven base \\
\hline 23212.sne7 & 620 & 73.5 & 6.3 & 7.5 & 12.7 & Oven make-up \\
\hline 23215.sne7 & 620 & 68.8 & 7.1 & 9.3 & 14.7 & Floor oven base \\
\hline 23215.sne3 & 620 & 79.2 & 11.5 & 6.3 & 3 & Oven make-up \\
\hline 23216.sne12 & 620 & 76.7 & 10.8 & 9.6 & 2.9 & Floor oven base \\
\hline 23216.sne 13 & 620 & 82.8 & 7.2 & 3.7 & 6.3 & Oven make-up \\
\hline
\end{tabular}

Table S1. Location, description of samples and main phytolith results obtained from non-chemically extracted samples (coded as sne) from the South Area. A minimum of 200 phytoliths were counted at $400 \times$. 


\begin{tabular}{|c|c|c|c|c|c|}
\hline $\begin{array}{l}\text { Unit/ } \\
\text { Sample } \\
\text { number }\end{array}$ & $\begin{array}{l}\text { Space/ } \\
\text { Building } \\
\text { (B) }\end{array}$ & $\begin{array}{l}\text { Monocotyledon } \\
\text { ous } \\
\text { (\%) }\end{array}$ & $\begin{array}{l}\text { Dicotyledonous } \\
\text { leaves } \\
\text { (\%) }\end{array}$ & $\begin{array}{l}\text { Dicotyledonous } \\
\text { wood/bark } \\
\text { (\%) }\end{array}$ & $\begin{array}{l}\text { Phytoliths } \\
\text { weathering } \\
\text { (\%) }\end{array}$ \\
\hline 23214.s12 & 620 & 63.7 & 31.6 & 1.9 & 2.9 \\
\hline $23214 . s 13$ & 620 & 71.3 & 21.3 & 3.2 & 4.2 \\
\hline 23214.s14 & 620 & 65.7 & 26.5 & 2.7 & 5.1 \\
\hline 23214.s15 & 620 & 55.3 & 34.6 & 3.7 & 6.5 \\
\hline 21898.s7 & 620 & 81.1 & 7.1 & 4.5 & 7.4 \\
\hline 23266.s1 & $\begin{array}{l}\text { B.17 wall } \\
\text { (West) }\end{array}$ & 80 & 5.9 & 2.2 & 11.9 \\
\hline 23266.s2 & $\begin{array}{l}\text { B.17 wall } \\
\text { (West) }\end{array}$ & 90.8 & 4.5 & 2.6 & 2.1 \\
\hline 23214.s16 & 620 & 86 & 4.6 & 3.8 & 5.6 \\
\hline 23214.s17 & 620 & 46.6 & 43.4 & 2.8 & 7.2 \\
\hline 23264.s1 & 620 & 40.7 & 47.2 & 3.1 & 9 \\
\hline 23264.s2 & 620 & 64.9 & 12.3 & 11.2 & 11.6 \\
\hline 21898.s5 & 620 & 85.3 & 5.2 & 3.9 & 5.6 \\
\hline 21898.s6 & 620 & 76.2 & 9.1 & 7.3 & 7.5 \\
\hline 23265.s1 & $\begin{array}{l}\text { B.17 wall } \\
\text { (South) }\end{array}$ & 85.2 & 6.1 & 3.3 & 5.4 \\
\hline $23212 . s 6$ & 620 & 78.5 & 6.1 & 10.4 & 5.1 \\
\hline 23212.s7 & 620 & 79.4 & 5 & 7.7 & 7.9 \\
\hline $23215 . s 7$ & 620 & 78.2 & 5 & 6.2 & 10.6 \\
\hline 23216.s12 & 620 & 80 & 9.5 & 4.6 & 6 \\
\hline $23216 . s 13$ & 620 & 83 & 7 & 4.4 & 5.7 \\
\hline 23214.s10.ss1 & $\begin{array}{l}\text { B.17 wall } \\
\text { (West) }\end{array}$ & 74.7 & 4 & 10.7 & 10.7 \\
\hline 23214.s10.ss2 & $\begin{array}{l}\text { B.17 wall } \\
\text { (West) }\end{array}$ & 81.7 & 5.9 & 5.2 & 7.2 \\
\hline 23214.s10.ss3 & 620 & 87 & 6.5 & 4 & 2.5 \\
\hline 23214-s10-ss4 & 620 & 53.1 & 41.4 & 3.8 & 1.6 \\
\hline 23214.s10.ss5 & 620 & 78.8 & 5.7 & 8.5 & 7.1 \\
\hline 23214.s10.ss6 & 620 & 86.1 & 5.5 & 4.8 & 3.7 \\
\hline 23214.s10-ss7 & 620 & 80.5 & 9.8 & 5.7 & 4 \\
\hline 23214.s11.ss1 & 620 & 78.4 & 5.5 & 7 & 9.1 \\
\hline 23214.s11.ss2 & 620 & 69.7 & 6 & 16.6 & 7.7 \\
\hline 23214.s11.ss3 & 620 & 76.2 & 10.7 & 4.8 & 8.2 \\
\hline 23214.s11.ss4 & 620 & 66.3 & 27.2 & 3.2 & 3.4 \\
\hline 23214.s11.ss5 & 620 & 77.5 & 9.7 & 5.9 & 6.9 \\
\hline
\end{tabular}




\begin{tabular}{llllll} 
23214.s11.ss6 & 620 & 68.9 & 11.2 & 9 & 10.9 \\
23616.s1.ss1 & 630 & 88.4 & 4.8 & 4.5 & 2.3 \\
23616.s1.ss2 & 630 & 86.7 & 5.6 & 5 & 2.6 \\
$23616 . s 1 . s s 3$ & 630 & 77.4 & 9.8 & 6.9 & 5.9 \\
$23616 . s 1 . s s 4$ & 630 & 81.1 & 7.9 & 9.4 & 1.6 \\
23616.s1.ss5 & 630 & 83.2 & 8.2 & 6.3 & 2.4 \\
23616.s1.ss6 & 630 & 82.9 & 7.2 & 5.8 & 4.2 \\
\hline
\end{tabular}

Table S2. Relative abundances of phytoliths obtained from spot samples (s) and micromorphological block sub-samples (ss). 


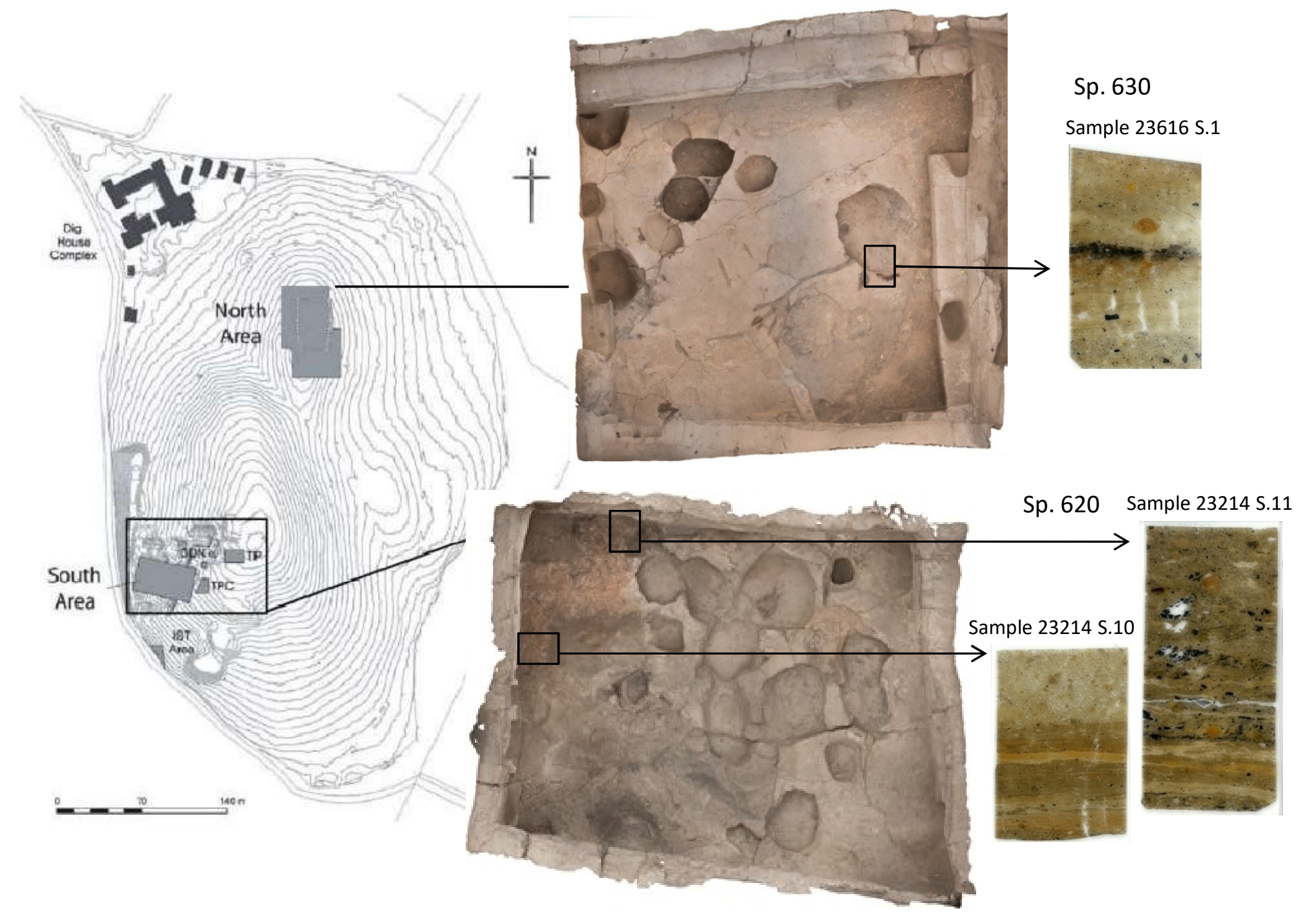

Fig. 1. Site plan of Çatalhöyük East with main excavation areas. Detailed view of Space 630 in the North Area (top) and plan view of Sp. 620 in the South Area (bottom) showing sampling locations. Sources: C. Mazzucato for Çatalhöyük Research Project (site plan) and J. Quinlan, M.Z. Barański and J. Tripkovic (ortophotos). 


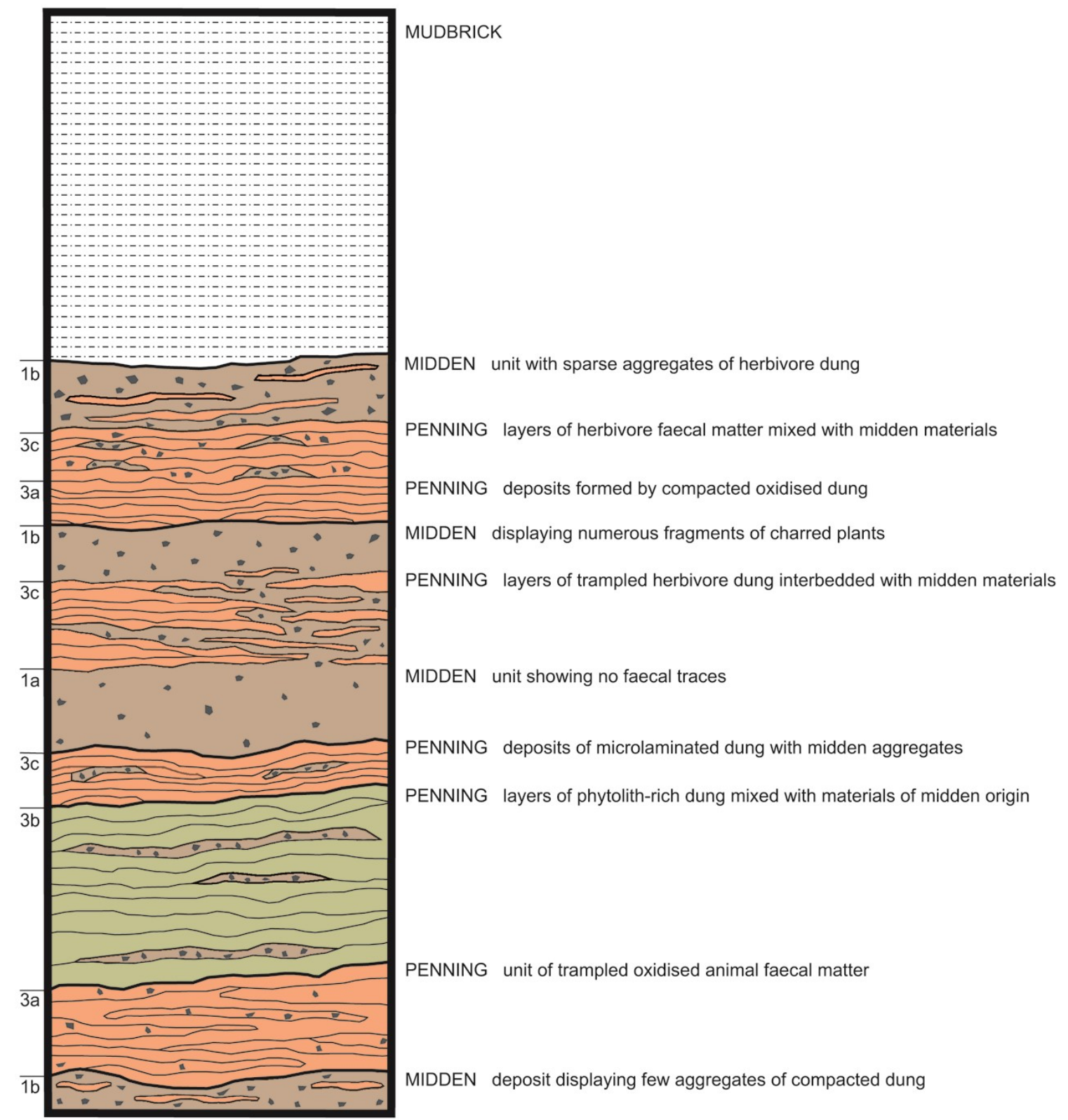

Fig. 2. Synthetic diagram of the microstratigraphic sequence in sample 23214.s10 displaying the bedding and composition of each microfacies. 

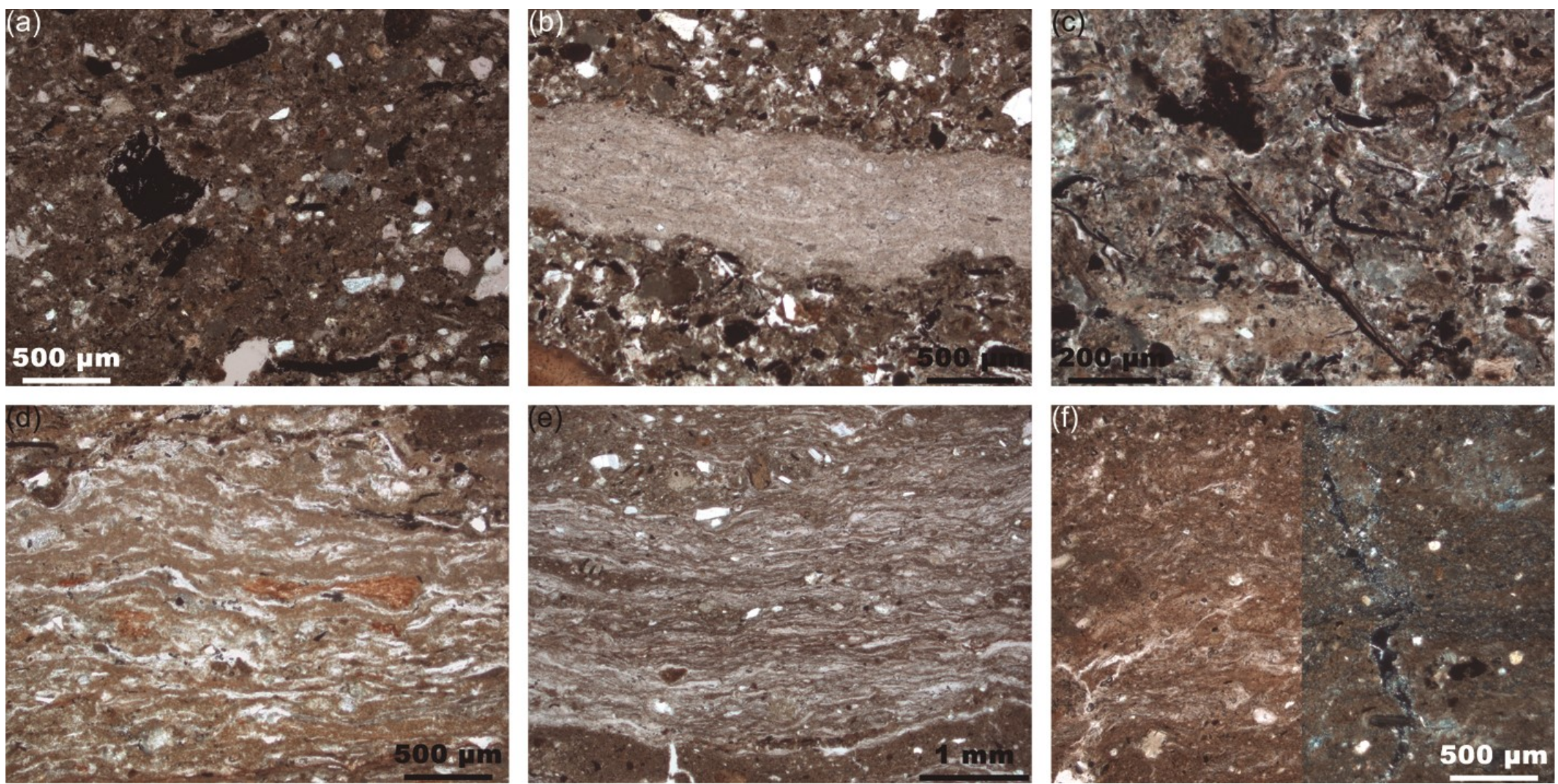

Fig. 3. Photomicrographs illustrating the different types of microfacies (MF) identified in Sp. 620 micromorphological samples $23214.11(a-b-c)$ and 23214.10 (d-e-f): (a) MF1a, heterogeneous midden displaying no traces of dung, PPL; (b) MF1b, lense of trampled herbivore dung in midden matrix, PPL; (c) MF2, calcitic ashes derived from the combustion of grasses and herbivore faecal matter, XPL; (d) MF3a, trampled layers of fibrous dung showing abundant phytolith and spherulite remains, including few bright orange patches from humified/lignified organic matter, PPL; (e) MF3b, penning deposits displaying phytolith-rich dung with partially decayed spherulites and few lenses of midden materials, PPL; (f) MF3c, heavily trampled dung intermixed with calcareous sediments and midden materials, PPL (left) and XPL (right). 

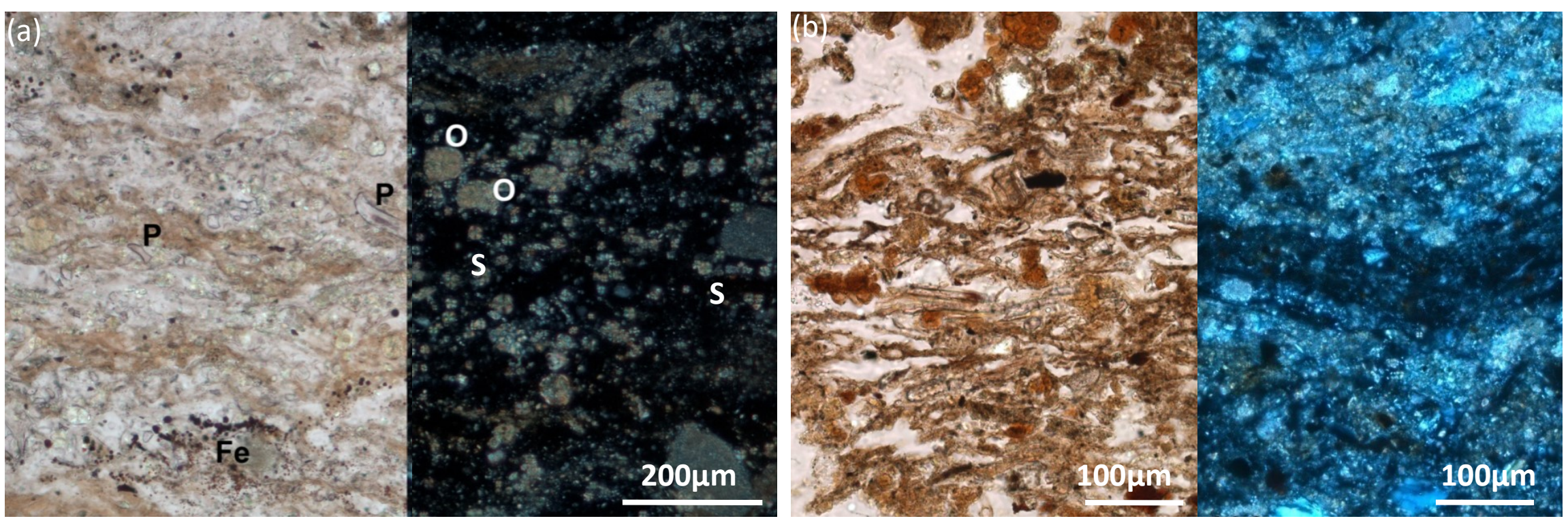

Fig. 4. (a) Photomicrograph of fibrous herbivore dung displaying abundant inclusions of partially digested phytoliths (P), calcium oxalates $(\mathrm{O})$ and calcitic spherulites $(\mathrm{S})$, and post-depositional staining $(\mathrm{Fe})$ in the form of framboid nodules of iron (oxy)hydroxides caused by the decay of organic matter in sample 23214.11, Sp. 620, PPL (left) and XPL (right); (b) compacted in situ banded herbivorous dung deposit with phytoliths in sample 23616.1, Sp. 630, PPL; (c) trampled ruminant dung with calcitic spherulites in sample 23616.1, Sp. 630, XPL. 

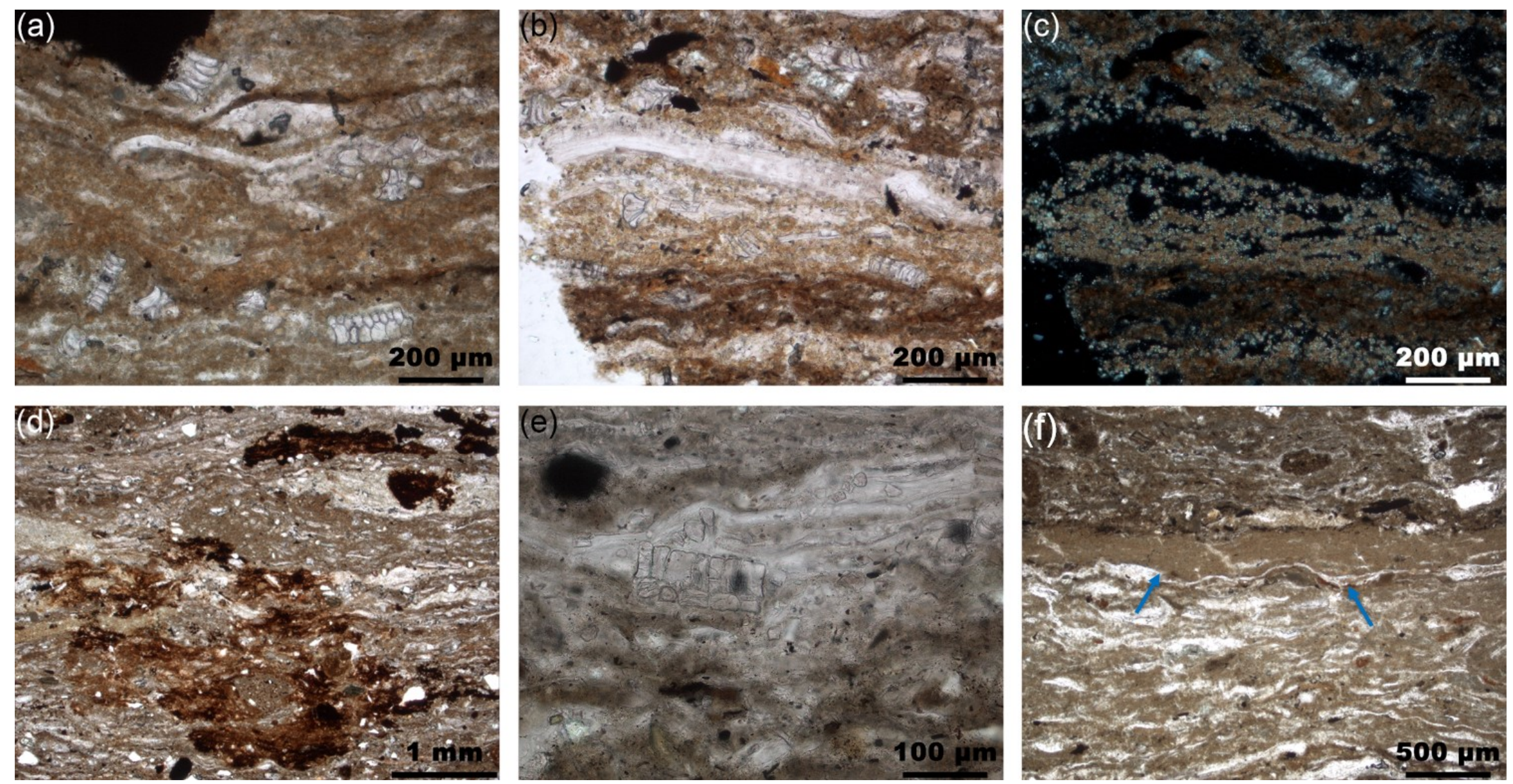

Fig. 5. Photomicrographs of key components found in penning deposits from Sp. 620 samples 23214.10 (a-b-c-d-f) and 23214.11 (e): (a) stacked bulliform phytoliths derived from reeds/grasses embedded in oxidised animal dung, PPL; (b) trampled herbivore faecal matter displaying well-preserved articulated phytoliths, PPL; (c) same as b, showing abundant calcitic spherulites, XPL; (d) ferruginous impregnative pedofeatures in penning layers, PPL; (e) multicellular phytoliths in fibrous dung deposit, PPL; (f) extremely compacted upper boundary in dung layer (arrows) due to the effect of intense trampling, PPL. 

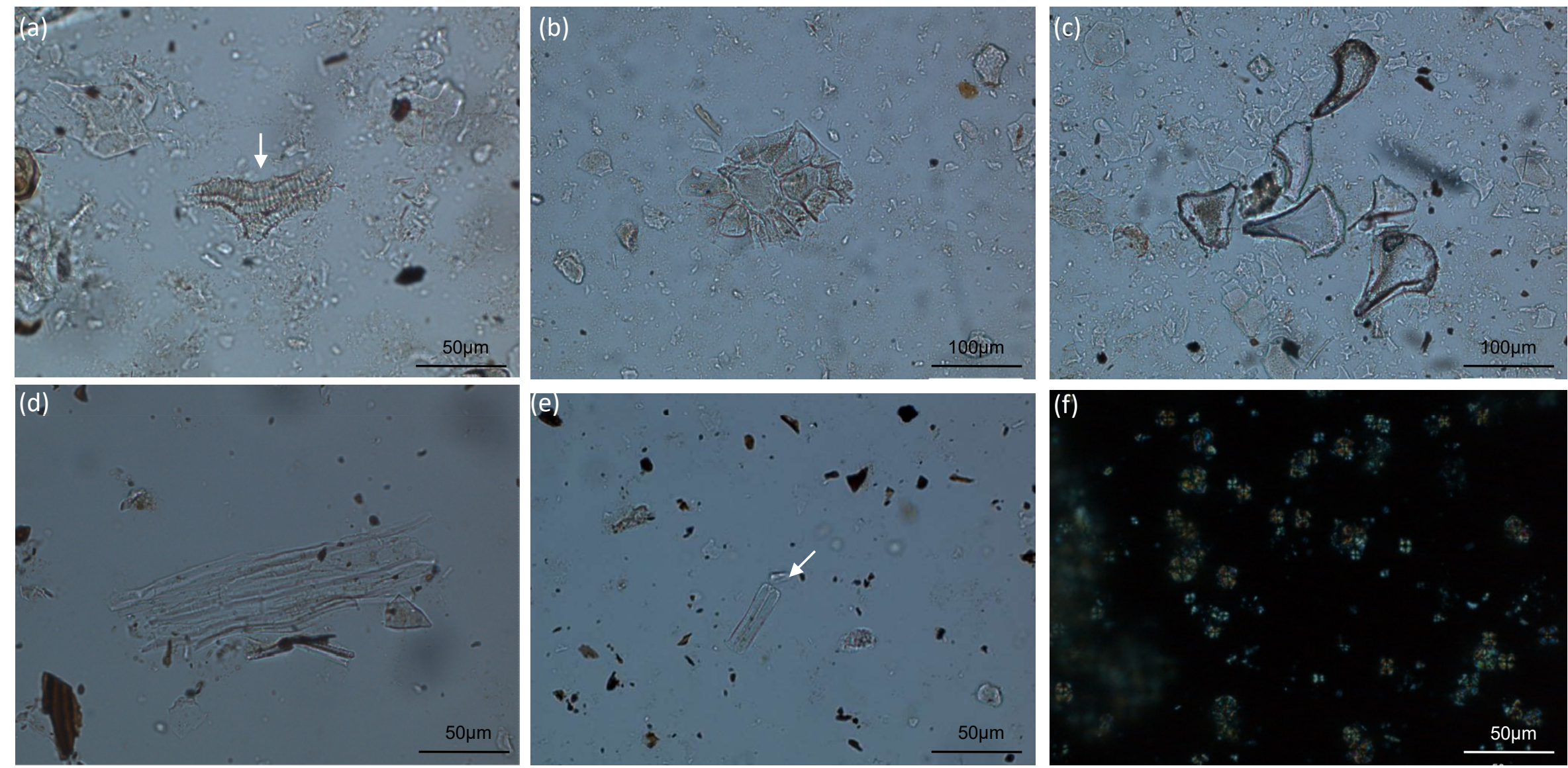

Fig. 6. Photomicrographs of phytoliths and other microfossils identified in Sp. 620, 23214 samples from penning deposits (200x or 400x). (a) Tracheary from dicotyledonous leaves, (b) epidermal base with attached appendage hair from dicotyledonous leaves, (c) bulliforms flabellate from monocotyledonous leaves, (d) articulated (multicellular) elongate phytoliths from grass leaves, (e) diatoms, (f) calcitic dung spherulites (XPL). 
Phytoliths $1 \mathrm{~g}$ of sediment (million) - Spherulites $1 \mathrm{~g}$ of sediment (million)

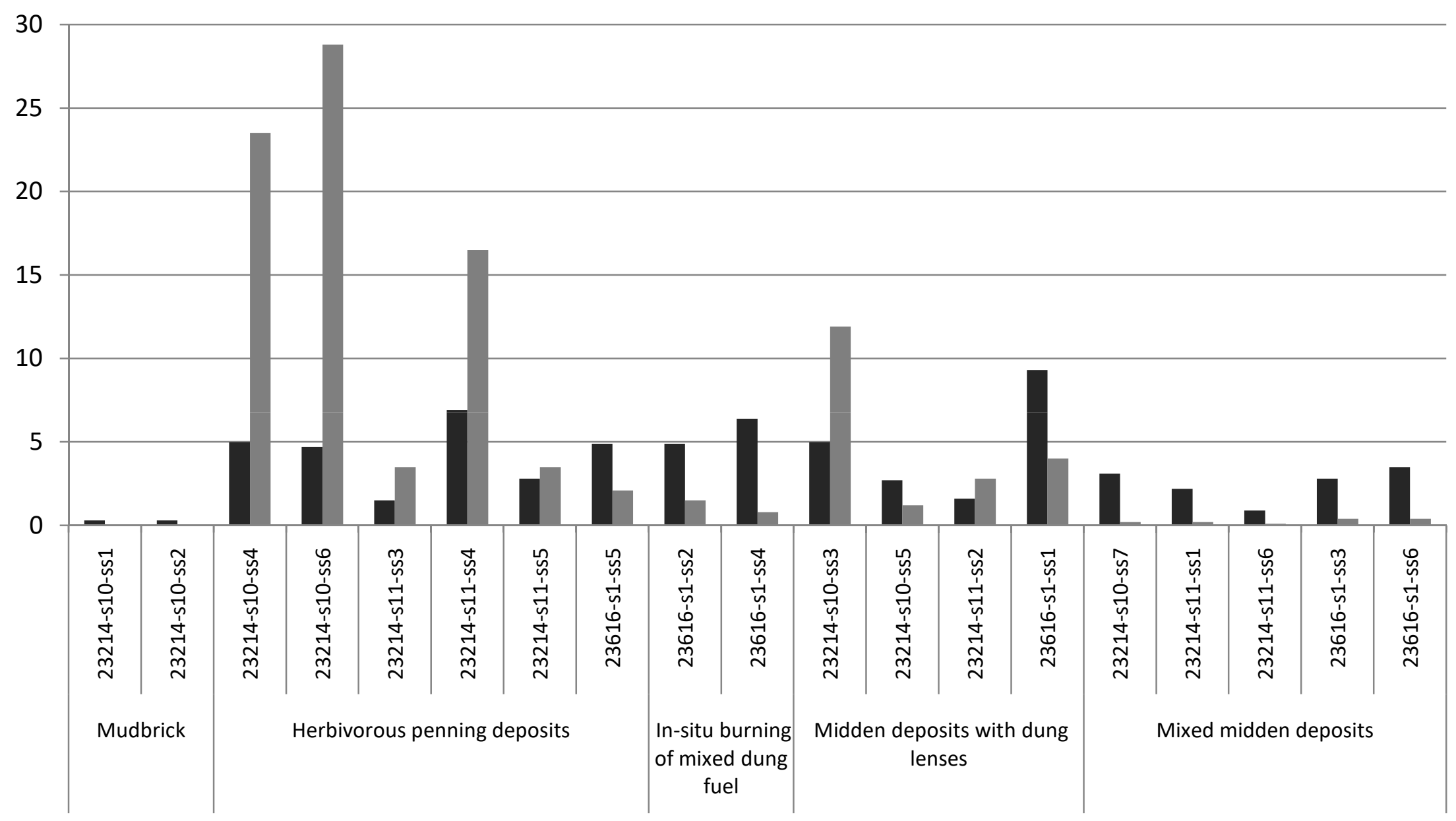

Fig. 7. Plot showing absolute concentrations of phytoliths vs. dung spherulites obtained from micromorphological block sub-samples for each of the contexts/deposit types analyzed. 

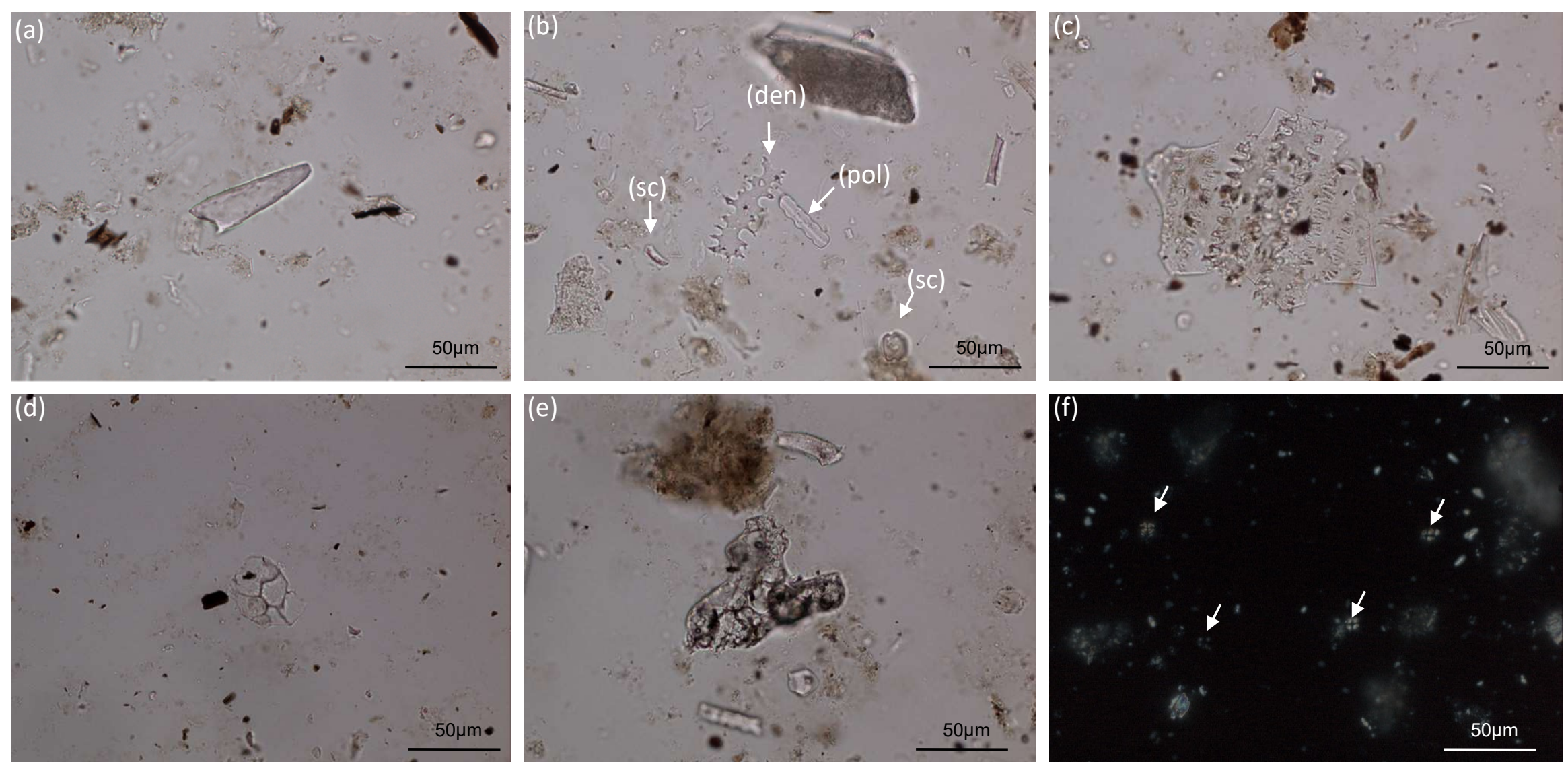

Fig. 8. Photomicrographs of phytoliths and other microfossils identified in Sp. 630, 23616.s1 sub-samples from penning (a-b-c) and mixed midden deposits displaying dung lenses (d-e-f) at 400x. (a) Epidermal appendage acute bulbosus (trichome) from grass leaves, (b) grass silica short cell phytoliths (arrows sc), elongate dendritic (den) and polylobate (pol) from grasses, (c) articulated (multicellular) dendritics with short cell rondels from the husk of Pooideae grasses, (d) epidermal appendage hair base from dicotyledonous leaves, (e) melted phytoliths, (f) dung spherulites (XPL). 